\title{
Non-invasive sampling of bats reflects their potential as ecological indicators of heavy metal and trace metal contamination due to open cast diamond mining, northern Limpopo Province, South Africa
}

Dawn Cory Toussaint ( $\nabla$ nycteris.cory2saint@gmail.com )

University of Venda https://orcid.org/0000-0002-3301-1609

Peter J. Taylor

University of the Free State - Qwaqwa Campus

Irene E. J. Barnhoorn

University of Venda School of Mathematical and Natural Sciences

\section{Research Article}

Keywords: Bioaccumulation, heavy metals, Chiroptera, ecotoxicology, biomarkers, opencast mining

Posted Date: April 15th, 2021

DOI: https://doi.org/10.21203/rs.3.rs-396952/v1

License: (c) (7) This work is licensed under a Creative Commons Attribution 4.0 International License. Read Full License 


\section{Abstract}

Bats have been proposed as reliable bioindicators for monitoring bioaccumulation of elements and chemicals in natural and transformed ecosystems. Non-invasive methods are becoming more popular as research moves away from destructive methodologies. We present the first concentrations of 23 elements in Mops condylurus and Tadarida aegyptiaca (Molossidae) fur and blood from an opencast diamond mine and control site using inductively coupled plasma mass spectrometry (ICP-MS). Concentrations of boron (B), potassium (K), rubidium (Rb) and cadmium (Cd) in the fur of bats were significantly higher in bats from the opencast diamond mine compared with the control site $(P=0.004,0.02$, 0.006 and 0.03 respectively). Manganese $(\mathrm{Mn})$, zinc $(\mathrm{Zn})$, antimony $(\mathrm{Sb})$ and mercury $(\mathrm{Hg})$ were significantly higher in the blood of bats from the mining footprint than the control area. Fifteen of the 22 elements (excluding barium $(\mathrm{Ba})$ ) were significantly higher in the fur samples than in the blood due to elements being incorporated over time into the fur as it grows, whereas blood reveals short-term exposure to elements.

Concentrations of most of the elements were reasonably low except Al, Fe and Zn. In general, the element concentrations particularly in the fur samples were comparable with other international studies reporting elemental fur concentrations from anthropogenically impacted and natural areas. Pending further research on toxic thresholds and physiological and ecological unknowns around element concentrations in bat tissues and organs, fur has the potential to be a viable indicator of toxicity.

\section{Introduction}

Heavy metals and trace elements are naturally occurring minerals present in the earth's crust, which under natural conditions, leach into water from the surrounding rock and soil, and are taken up by plants and animals (Garret 2000, Nagajyoti et al. 2010, Flache et al. 2015). We follow the re-defined definition of heavy metals and trace elements by Bánfalvi (2011) (see Table 1) where trace elements (or macronutrients) are elements that are naturally present in the soil in minute quantities $\left(100 \mu \mathrm{g} \cdot \mathrm{g}^{-1}\right)$ and are required by plants and animals for biological function, growth and

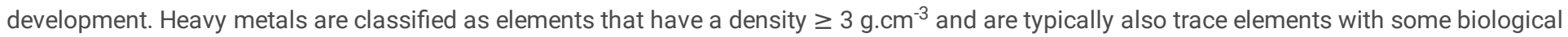
functionality at low concentrations (Bánfalvi 2011). These elements become toxic at concentrations higher than what is physiologically required by an organism (Aggett 1985, Nagajyoti et al. 2010, Tchounwou et al. 2012, Flache et al. 2018). There are also heavy metals and trace elements that are considered non-essential elements as they have no known physiological role or function and can be toxic at low concentrations (Reis et al. 2010, Zukal et al. 2015, Ferrante et al. 2018, Kolarova and Napiórkowski 2021).

Element (heavy metals and trace elements) bioaccumulation, toxicity and resulting effects have been a subject of interest for many years (Jakimska et al. 2011, Bat et al. 2020). The concentrations of elements released from natural sources depends on release process (natural versus anthropogenic), geochemical properties of parent rock material, environmental conditions and the weathering process (Garret 2000 , Tchounwou et al. 2012). Natural releases of elements are exacerbated by anthropogenic activities that results in the accumulation of high concentrations of these elements in the soil often near the source of emission (Nagajyoti et al. 2010, Flache et al. 2015, Obrist et al. 2018). Sources of anthropogenic element releases are in the form of fertilizers (organic and inorganic), pesticides, agricultural practices (including continued irrigation of agricultural crops resulting in leaching and surface runoff), mining activities and associated transport and processing of ore (dust fallout, smelting, amalgamation processes), paper and plastic processing, wood preservation, waste water treatment plants and urban storm water runoff (Nagajyoti et al. 2010, Naidoo et al. 2016, Moreno-Brush et al. 2018, Carrasco-Rueda et al. 2020). But, even remote areas do not escape metal contamination as some metals emitted through anthropogenic activities and volcanic eruptions, like mercury that linger in the atmosphere up to a year, are able to be transported over vast distances in the atmosphere and contaminate areas far from the point of emission (Nagajyoti et al. 2010, Flache et al. 2018).

Bioavailability of these elements is complex and consists of three parts as detailed in Kim et al. (2015). Firstly, the total concentrations of elements in the soil that is referred to as "environmental availability". Secondly, the fraction of the dissolved elements in pore water (water in the spaces between the soil particles) is called the "environmental bioavailability". These dissolved elements are thus available to be taken up by soil organisms and plant roots. And lastly, "toxicological bioavailability", is accumulation of element/s in an organism or the physiological effect induced but elements. Bioavailability depends on several factors; temperature, adsorption and sequestration (removal and storage), absorption, phase association, chemical factors (the state of the element - solid, liquid or gas and how they interact with other elements/molecules, lipid solubility etc.) and biological factors (trophic interactions, characteristics of species, physiological or biochemical adaptations etc.) (Tchounwou et al. 2012). Bioaccumulation of elements in an organism is generally influenced by specific location, age of the organism and its interactions with the environment (Sánchez-Chardi and Nadal 2007) and can enter into the food chain directly from sediment into organisms, by drinking from contaminated water sources or feeding on contaminated plants or prey items, inhalation from the air/dust and dermal exposure (Reis et al. 2010, Gall et al 2015, Hernout et al. 2016b). For example, heavy metals are known to accumulate in marine sediments, affect benthic life and become a risk for humans consuming marine organisms such as sea cucumbers (Bat et al. 2020). There are a number of organisms ranging from invertebrates, to shrews, rodents, birds, and sea cucumbers that are suggested as suitable bioindicators for heavy metal and trace element exposure (Dallinger 1994, Sánchez-Chardi et al. 2007, Egwumah et al. 2017, Bat et al. 2020). Data on element toxicity effects in wild animals is limited and it is challenging to provide a concentration range of heavy metal and trace elements that reflects "normal" conditions in organs and tissues (Sánchez-Chardi et al. 2007). 
The effects and impacts of heavy metal, chemical pollutants and other elements that bats have been and are currently exposed to is gaining increased attention (Zocche et al. 2010, Griffiths et al. 2014, Lovett and McBee 2015, Naidoo et al. 2016, Carrasco-Rueda et al. 2020). Heavy metal pollution has been shown to affect bat ecology, genetics, physiology and behaviour. Effects of element pollution include but are not limited to changes relating to bat diversity, alteration of relative abundances, population structure changes, negative impacts on flight activity, disruption of plasma glucocorticoids, central nervous system alterations (causing a general lack of coordination, loss of movement, tremors, paralysis), damage to internal organs (renal inclusion bodies), hemochromatosis ("iron overload"), immunosuppression and mortality (Zocche et al. 2010, Zukal et al. 2015, Naidoo et al. 2016, Mina et al. 2019).

Bats may be directly exposed to elements through drinking from contaminated water sources or through the accumulation of elements in prey items that breed in polluted waterbodies (Pikula et al. 2010, Mansour et al. 2016, Mina et al. 2019). Bats are also indirectly exposed to pollutants through human activities that may change the physical habitat and alter availability and quality of resources (food and water) (Zocche et al. 2010, Gall et al. 2015). Even at low concentrations, lead (Pb), Fe, Cu, Mn, cadmium (Cd), Ni and aluminium (Al) are known to be toxic, damaging DNA, causing gene mutations and cancers (Beyersmann and Hartwig 2008, Naidoo et al. 2013) but the concentration at which these metals are toxic and or fatal to bats is unknown. Zocche et al. (2010) reported preliminary results that the exposure to and resulting uptake of elements associated with coal mining such as $\mathrm{Al}$, silicon ( $\mathrm{Si}$, , Mn, Fe, $\mathrm{Cr}, \mathrm{Cd}, \mathrm{Zn}, \mathrm{Pb}, \mathrm{Cu}$ and $\mathrm{Ni}$, resulted in DNA damage in Eptesicus diminutus and heavy metal accumulation in Molossus molossus and Tadarida brasiliensis. They suggested that the above bat species occurring in the Carboniferous Basin of Santa Catarina could be used as bioindicators species for ecosystems that are directly and indirectly affected by coal mines to detect bioaccumulation of heavy metals (Zocche et al. 2010).

Persistent environmental pollutants are an underrated threat to bats and the manner in which contaminants transfer, bio-magnify through trophic levels and accumulate within an organism (in tissues and organs) is fairly complex (Clarke et al. 1986, Flache et al. 2018, Mina et al. 2019). Different bat species may show specific trace element concentrations in their tissues and organs associated with variations in exposure within different foraging habitats, dietary guilds and physiological regulation of elements (Karouna-Renier et al. 2014, Zukal et al. 2015, Flache et al. 2015, Hernout et al. 2016b, Becker et al. 2018, Flache et al. 2018, Moreno-Brush et al. 2018, Carrasco-Rueda et al 2020, de Souza et al. 2020). There could be numerous instances where high levels of metals may not be due to the contamination of the environment, but may be an artefact of the bat's diet. E.g. Myotis myotis has been reported to contain high levels of Mn that may come from their predominant carabid beetle diet which reportedly strengthen their mandibles with Mn (Flache et al. 2015). It is evident from the literature, that different species of bats are exposed to different types of contaminants based on their dietary guild, sex, age and seasonality (Clark et al. 1986, Naidoo et al. 2013, Hernout et al. 2016b, de Souza et al. 2020). However, this differs depending on the element and possibly species for example; no differences in concentrations of mercury in the fur of Carollia perspicillata and Phyllostomus elongatus were found to be attributed to sex and age, which indicated that $\mathrm{Hg}$ was not accumulated over time (Moreno-Brush et al. 2018).

Bats are good potential bioindicators for ecosystem health due to their small size, high mobility, high metabolic rates and associated high prey intake of between $40-100 \%$ of their body weight each night, global distribution and coexistence with humans thus increasing their exposure to a range of contaminants (Hickey et al. 2001, Jones et al. 2009, Russo and Jones 2015, Zukal et al. 2015). Bat species of particular interest are those that feed on emerging insects such as Trichoptera which have an aquatic larval stage, typically live in sediment, accumulate metals, and thus provide a pathway for contaminants to pass from aquatic to terrestrial ecosystems (Zukal et al. 2015, Mina et al. 2019). Being the second highest species-rich mammalian order in the world representing approximately $20 \%$ of global mammal diversity, bats form a large component of global biodiversity and deliver key services to both ecosystems and humans (pest control, pollination, seed dispersal and forest regeneration) (Jones et al. 2009, Kasso and Balakrishnan 2013, Bayat et al. 2014, Riccucci and Lanza 2014, Taylor et al. 2018).

The acquisition of biological material to use as biomarkers from wildlife is moving towards non-invasive and non-destructive methods mainly from an animal ethical and conservation perspective (Hernout et al. 2016b, Powolny et al. 2019). Brain, blood, liver, kidney and whole animal sampling for the determination of biomarkers and elemental contamination in bats are highly-invasive (e.g. liver, kidney biopsies) or destructive sampling methodologies (e.g. Smith and Rongstad 1982, Naidoo et al. 2013, Flache et al. 2018). The liver, kidneys and other internal organs are known organs for deposition of ingested heavy metals and the concentrations of heavy metals in these organs reflect the level of exposure and accumulation of these elements over a prolonged period (Naidoo et al. 2013). It is for these reasons that these organs are such good biomarkers and have been widely used (e.g. livers of fish; Dragun et al. 2019, kidneys and or liver of bats; Zocche et al. 2010 and Hernout et al. $2016 a$, kidneys of mink and otters; Harding et al. 1998). Using fur could be a good biomarker as the roots are constantly in contact with bloodstream thus metals may be incorporated into the fur during growth and additionally fur also stores external airborne particles, thus external exposure and ingestion of elements could be investigated (de Souza et al. 2020). Fur provides an indication of the long-term exposure to elements and provides information concerning the exposure of an animal at the time of the tissue formation (Fraser et al. 2013, Hernout et al. 2016b). E.g. Flache et al. 2015 used bat fur to monitor bat's exposure to potentially toxic metals in their foraging habitat and reported trace metal concentrations of Cd, Cu, $\mathrm{Mn}, \mathrm{Pb}$ and $\mathrm{Zn}$ in fur samples collected from Myotis bechsteinii, M. daubentonii, M. myotis and Pipistrellus pipistrellus.

Metal concentration in fur varies at different times of the year e.g. fur collected prior to the annual moult cycle may contain higher metal concentrations than those during or after the moult therefore the moult cycle must be taken into consideration when collecting samples (Fraser et 
al. 2013, Flache et al. 2015, Hernout et al. 2016a). The moult cycles of bats has not been well studied (particularly in South Africa) and Fraser et al. (2013) provided a summary of the moult cycles of $\sim 27$ bat species and highlighted that timing and pattern of the moult differed between species, sex, reproductive status and age. Blood, on the other hand, provides information concerning a more recent exposure as it is gradually replaced (Fraser et al. 2013). Powolny et al. (2019) showed that in wood mice (Apodemus sy/vaticus) sampled along a pollution gradient, blood could be a good indication of internal organ levels of $\mathrm{Se}, \mathrm{Pb}$ and Thallium (TI). On the contrary, blood concentrations of titanium (Ti), $\mathrm{Cd}$, Fe, $\mathrm{Cu}$, Mo and Zn were not good indicators of internal organ concentrations (Powolny et al. 2019).

We investigated the elemental concentrations in blood and fur of two species of open-air foragers; Mops condylurus (Angolan free-tailed bat; A. Smith 1833) and Tadarida aegyptiaca (Egyptian free-tail bat; É. Geoffroy Saint-Hilaire 1818) collected during summer. Our aim was to determine if bats would be suitable bioindicators for the monitoring of ecosystem health over and near opencast diamond mining operations using nonlethal and non-invasive methods. We expect that bioaccumulation of heavy metals in bats fur and blood is significantly higher over mining areas than the adjacent control area. Alternatively we may find no difference in heavy metal concentration in the fur and blood of bats active over the opencast mine and adjacent control area. We also determined if there were any correlations between concentrations of elements between fur and blood to investigate if fur could be a reliable indicator of internal element concentrations.

\section{Materials And Methods}

\section{Study site}

The study was conducted on the De Beers Venetia diamond mine, in the Limpopo Province $\left(-22.449593^{\circ}, 29.319494^{\circ}\right)$ and Corea Game Farm $\left(-22.462280^{\circ}, 29.256442^{\circ}\right)$ (Figure 1). The Venetia diamond mine has been in operation since 1992 (https://www.debeersgroup.com/thegroup/our-history) in the Limpopo mobile belt, where a complex kimberlite pipe containing diamonds is situated (Brown et al. 2009). A temporary water pan on Corea Game Farm was used as the control site that was situated $\sim 5 \mathrm{~km}$ in a straight line from the large wastewater dam on the western side of the mining footprint and $\sim 6.5 \mathrm{~km}$ from the bat roosting site (Figure 1). Corea Game Farm is situated within the diverse Musina Mopane Bushveld vegetation unit dominated by mopane trees (Colophospermum mopane) on poorly developed soils (Mucina and Rutherford, 2011). The mine footprint is situated in the Limpopo Ridge Bushveld, which is also dominated by mopane trees. The climate of the area is characterised by very dry winters and hot summers with mean annual precipitation between 300-400mm (Mucina and Rutherford, 2011).

\section{Bat capture}

Bat capture was conducted over five nights (3-7 December 2018) on the Venetia diamond mine and seven nights (1-2, 8-11 \& 13 December 2018) on Corea Game Farm. Free standing nylon monofilament mist nets (ECOTONE, Gdynia, Pomerania, Poland) and an Austbank harp trap (Faunatech, Australia) were used to capture bats. On the mine, free standing mist nets of $9 \mathrm{~m}$ and $12 \mathrm{~m}$ were extended parallel to edge of waste water dams. Due to the tempestuous summer weather and resulting billowing motion of the free-standing mist nets, capture success in the mist nets was poor on the mine. An Austbat two-bank harp trap was placed at the entrance/exit of a known roost of free-tailed bats (Molossidae) in an unused building on the Venetia diamond mine to capture individuals from the roost. Trapping on Corea game farm consisted of two sets of $9 \mathrm{~m}$ and $12 \mathrm{~m}$ mist nets strategically placed across temporary water pans. Two mist nets were placed one above the other to have a resulting drop of $\sim 5 \mathrm{~m}$. All captured bats were initially held in cotton bags, processed and identified to species level. Mops condylurus were captured on the mining footprint and T. aegyptiaca dominated the control site. Female bats dominated over males during the active capture sessions particularly over the control area, with only a single male captured on Corea Game Farm. Four males and seven females were selected from the captured individuals. It would have been ideal to only have males representing the sample as in some instances, sex and reproductive status effects element concentrations in some bat species e.g. females eliminate metals better than males through lactation (Hernout et al. 2016b).

Faecal pellet preparation and insect reference sampling.

Each cotton holding bag was inspected and faecal pellets were collected in order to identify if captured bats were consuming insect orders that had an aquatic life-cycle phase. A light trap consisting of an 11 watt (600 lum) warm-white light bulb suspended over a container of water and powered by a portable power unit (EcoBoxx Qube 160, South Africa) was used to collect a representative sample of arthropods available to bats foraging over the mining footprint and over the temporary water pan on Corea Game Farm. The light trap was regularly checked and insects were collected. Insects were sorted predominantly to order level and where possible to family or species. Representative individuals of each order/family were crushed into fine pieces with a pestle to simulate the grinding action of a bat's teeth and mounted between two microscope slides (Lasec Laboratory \& Scientific Equipment Company (pty) Ltd.). Each insect order was weighed to calculate percentage abundance to determine what was available to foraging bats during the sample period. Faecal pellets were softened using $98 \%$ ethanol and spread between two slides. The faecal pellets and insect remains were inspected and photographed using a Zeiss Stemi 508 microscope (Karl Zeiss, Germany) fitted with a $4 \mathrm{mp}$ Axiocam ERc 5s (Rev. 2.0) camera. Arthropod remains in the faecal pellets were identified to order and where possible family using the arthropod key in Kunz and Parsons (2009) and the study reference samples identified using Picker et al. (2004). Percentage frequency for each arthropod order was visually estimated in accordance with Kunz and Whitaker (1983). 
Since the collection period was during December, we assume that the bats had already had their annual summer moult (Fraser et al. 2013). Fur was collected using a pair of sharp surgical scissors (Lasec, Laboratory \& Scientific Equipment Company (pty) Ltd.). Fur was carefully clipped from the dorsal side of the bat, as close to the skin as possible, starting from the pelvic region and ending between the scapulars. Individual fur samples were immediately placed into small zip-lock bags and marked.

Blood was only taken from males and reproductively inactive females; not pregnant nor lactating. Blood samples were taken from each bat in line with Smith et al. (2010). Each bat was gently restrained in the left hand. The left wing was carefully extended to expose the inner upper arm which was then sanitised using an alcohol swab. Slight pressure was applied to the branchial vein near the base of the upper arm and the tip of a sterile 24 gauge needle was used to puncture the vein. The resulting bead of blood was sampled using $125 \mu \mathrm{L}$ heparinised clinitubes (Radiometer, Denmark). Acceptable volumes of blood between $62.5 \mu \mathrm{L}-120 \mu \mathrm{L}$ were taken $\left(2.9 \mu \mathrm{L} . \mathrm{g}^{-1}-5.5 \mu \mathrm{L} . \mathrm{g}^{-1}\right.$ respectively) (Smith et al. 2010). A small butane torch (Zengaz, ZT-50) was used to melt the ends of the capillary tubes and with a quick twist of the melted glass, the ends were sealed. The blood samples were immediately refrigerated.

Fieldwork was conducted with approval of the animal ethics clearance by Research and Innovation, Office of the Director, University of Venda, Project No: SMNS/19/ZOO/02/0307. All bats sampled survived and were successfully released at their respective sites of capture. Bats captured on Corea Game Farm were processed the same night of capture and immediately released. Only the bats captured from the Venetia diamond mine using the harp trap were held for $\sim 12$ hours due to mine security access and were offered mealworms and water prior to release back on the mine the following evening.

\section{Trace elements and heavy metals by ICP-MS}

Eleven fur and blood samples were tested for heavy metals antimony (Sb), arsenic (As), barium (Ba), cadmium (Cd), chromium (Cr), cobalt (Co), copper ( $\mathrm{Cu})$, iron (Fe), lead (Pb), manganese (Mn), mercury ( $\mathrm{Hg})$, molybdenum (Mo), nickel (Ni) tin (Sn), vanadium (V) and zinc ( $\mathrm{Zn})$, and trace elements aluminum (Al), boron (B), calcium (Ca), potassium (K), rubidium (Rb), selenium (Se) and strontium (Sr) (Table 1). The elemental analysis was conducted by the Central Analytical Facility (CAF), University of Stellenbosch, Western Cape using an Agilent 7900 quadrupole inductively coupled plasma mass spectrometer (ICP-MS). Biological samples were weighed directly into $15 \mathrm{ml}$ acid cleaned Falcon ${ }^{\circledR}$ tubes. 0.25 $\mathrm{ml}$ Ultra-pure Nitric and $0.25 \mathrm{ml}$ Ultra-pure Hydrogen peroxide was added to each tube. The tubes were then placed in an oven at $60{ }^{\circ} \mathrm{C}$ for 30 minutes. After samples were digested, $2 \mathrm{ml}$ of Ultra-pure de-ionised water. Detail on analytical conditions for the ICP-MS is included under Supplementary Material: ICP-MS Analysis Detail. Concentrations of metals in fur and blood were reported as $\mu \mathrm{g} . \mathrm{g}^{-1}$ and $\mu \mathrm{g} \cdot \mathrm{ml}^{-1}$ and for the statistical analysis, were converted to parts per million (ppm).

\section{Statistical analysis}

Data was analysed in R (Version 1.1.456, RStudio, Inc.). Results of element concentrations in fur and blood are presented as median and range as the values in many instances varied considerably.

Each element concentration data set of the bat fur and blood were tested individually for normality using Shapiro tests $(P<0.05$ not-normally distributed and $P>0.05$ normal distribution). Nonparametric Mann-Whitney $U$ tests (wilcox.test, conf.int $=$ TRUE) were used where data did not have a normal distribution. Anovas (anova(aov)) were run where data had a normal distribution. Where two data sets that were compared differed in their distribution, a two-sample t-test assuming unequal variances was used (Excel). Spearman's correlation coefficient in R (cor.test) was used to determine if there were any correlations between the element concentrations in blood and fur.

\section{Results}

\section{Dietary analysis}

Isoptera were present in 20 of the 22 faecal pellets with evidence of Coleoptera, Hymenoptera and Lepidoptera in one faecal pellet and Hemiptera present in two faecal pellets (Table 2). Coleoptera dominated the light trap samples on both the mining and control sites comprising $53.92 \%$ and $37.74 \%$ of the sample respectively (Figure 2). Isoptera were the second dominant insect order comprising $17.16 \%$ of the sample collected in the control site but their presence was negligible on the mine area (Figure 2).

\section{Trace elements by ICP-MS}

Six M. condylurus from the Venetia diamond mine and four T. aegyptiaca and one M. condylurus were selected from the control area (Corea Game Farm) for the analysis (Table 2). Elements $\mathrm{Cd}, \mathrm{Co}, \mathrm{Cr}$, Mo, Ni and Sb were below detection limits in several individual bats, thus half the detection limits provided by CAF was used in the analysis (Hickey et al. 2001, Andreani et al. 2019). Barium was only detectable in three out of 11 fur samples with concentrations $\left(\mu \mathrm{g} . \mathrm{g}^{-1}\right)$ of $1.07,1.51$, and 2.26 . In all blood samples, Ba was below the detection limit and was therefore not 
included in the statistical analyses. Table 3 shows the detail of the statistical analyses used based on the distributions of the data set pairs that were analysed using Mann-Whitney $U$ tests, Anovas and t-tests assuming unequal variances.

Concentrations of elements varied greatly for most elements (Table 4). Overall, fur and blood concentrations for most of the heavy metals and trace elements were fairly low except for fur concentrations of Al, Fe and $\mathrm{Zn}$ with overall median concentrations ( $\mu \mathrm{g} . \mathrm{g}^{-1}$ ) of $104.88,120.24$ and 121.68 respectively (Figure 3 , Table 4 ). With the exception of Fe where a higher concentration was recorded in blood than fur $(P<0.0005)$, concentrations of elements were generally higher in fur than blood, and significantly so for elements $\mathrm{Al}, \mathrm{As}, \mathrm{B}, \mathrm{Ca}, \mathrm{Co}, \mathrm{Cr}, \mathrm{Cu}, \mathrm{Hg}, \mathrm{Mn}, \mathrm{Ni}, \mathrm{Pb}, \mathrm{Sb}, \mathrm{Sr}$, and $\mathrm{V}(P<0.005$, Table 3, Figure 3$)$

The bats from the mining footprint had significantly higher fur concentrations of $\mathrm{B}, \mathrm{Cd}, \mathrm{K}$ and $\mathrm{Rb}(P \leq 0.03)$ than those from the control site (Table 3). The maximum concentrations $\left(\mu \mathrm{g} . \mathrm{g}^{-1}\right)$ were $18.9,7.30,2.96$ and 0.171 respectively from the mine. Although not statistically significant, it is interesting to note that bats fur from the control site had higher maximum concentrations of $\mathrm{Al}\left(558.06 \mu \mathrm{g} . \mathrm{g}^{-1}\right), \mathrm{V}\left(1.24 \mu \mathrm{g} . \mathrm{g}^{-1}\right), \mathrm{Cr}\left(2.71 \mu \mathrm{g} . \mathrm{g}^{-}\right.$ $\left.{ }^{1}\right), \mathrm{Mn}\left(32.61 \mu \mathrm{g} \cdot \mathrm{g}^{-1}\right)$, Fe $\left(814.00 \mu \mathrm{g} \cdot \mathrm{g}^{-1}\right)$, Co $\left(0.673 \mu \mathrm{g} \cdot \mathrm{g}^{-1}\right), \mathrm{Sr}\left(3.651 \mu \mathrm{g} \cdot \mathrm{g}^{-1}\right)$ and $\mathrm{Pb}\left(1.465 \mu \mathrm{g} \cdot \mathrm{g}^{-1}\right)$ than the fur from bats roosting on the mine.

Blood element concentrations for the most part were comparable between the two sites except for Mn, Zn, Sb and Hg. These four elements were significantly higher $(P \leq 0.05)$ in the blood of the bats from the Venetia diamond mine with maximum concentrations $\left(\mu \mathrm{g} . \mathrm{ml}^{-1}\right)$ of $0.43,7.04$, 0.003 and 0.05 recorded from the blood of bats roosting on the mine (Table 3 and 4). The highest concentration of a heavy metal was recorded for Fe in blood that ranged from a minimum concentration of $484.83 \mu \mathrm{g} \cdot \mathrm{ml}^{-1}$ from the control site to $1026.21 \mu \mathrm{g} . \mathrm{ml}^{-1}$ from the mine. Statistically, there was no difference in blood and fur Fe concentrations between the control and mining footprint. The only significant correlation between fur and blood element concentration was for $\mathrm{Hg} ; P=0.02$, rho $=0.69$. There may well be other correlations between element concentration in fur and blood but a larger sample size is needed to determine any potential correlations.

\section{Discussion}

We provide the first data for a range of 23 elements using fur and blood as biomarkers in two open-air forager bat species, $M$. condylurus and $T$. aegyptiaca from northern Limpopo Province, South Africa. Tadarida aegyptiaca predominantly feeds on Coleoptera (including water beetles), Lepidoptera, Orthoptera, Hymenoptera, Isoptera, Diptera and Arachnids (spiders) (Taylor et al. 2019, Monadjem et al. 2020). Mops condylurus feeds mainly on Coleoptera, Hemiptera, Diptera and Lepidoptera (Taylor et al. 2019, Monadjem et al. 2020) and during sample collection, fed mostly on Isoptera that emerged in response to the onset of the rainfall season. This suggests that the bats roosting on the mine were not foraging in the vicinity of the mist net capture sites on the mine where the insect sampling took place but possibly over the natural areas adjacent to the mine. It is known that elements bioaccumulate through trophic levels (Pikula et al. 2010, Ali et al. 2019) but element concentrations in bat diets is largely unknown. In general the diet of different bat species has been shown in the literature to be an important route through which heavy metals and trace elements could accumulate in tissues and organs of bats (Karouna-Renier et al. 2014, Becker et al. 2018, Carrasco-Rueda et al. 2020). Idowu et al. (2014) and Denloye et al. (2015) presented fairly low concentrations of heavy metal accumulation in mound termites (Termitidae) that are fondly consumed by people in Africa. The latter authors cautioned that even though the concentrations of heavy metals in the different species and castes were low, the different species and castes of termite may have different abilities to accumulate heavy metals based on their physiological needs and could pose a risk to humans regularly consuming them. Termites may provide a seasonal source of heavy metal and trace element ingestion in molossid bats and other bat species that opportunistically feed on them during the summer emergence.

Fifteen of the 22 elements investigated (excluding $\mathrm{Ba}$ ) showed significant differences between fur and blood, with 14 elements being reported higher in fur than blood (Figure 3). Only Fe was found to be higher in blood than in the fur with approximately a seven fold difference in the medians between the two sites (Figure 3). Correlations between tissues and internal organs are not standard and cannot be generalised. In our study, a novel finding was that only $\mathrm{Hg}$ had a significant (although weak) correlation between fur and blood concentrations that is supported by a similar finding by Karouna-Renier et al. (2014). They found that $\mathrm{Hg}$ concentrations in the blood of M. lucifugus were highly predictive by fur Hg concentrations (Karouna-Renier et al. 2014). There are currently no toxic thresholds of heavy metals and trace elements for fur concentrations and internal organs/tissues in bats. For all intents and purposes, until the toxic thresholds for heavy metals and trace elements in various bat species has been determined, we may refer to toxic thresholds of elements reported for other mammalian species as a reference, although we acknowledge that this may significantly differ for bats. Clark et al. (1986) suggested that heavy metal accumulation in the kidneys of bats should be compared with that of shrews, as they have a similar diet opposed to mice. However, toxic thresholds of heavy metals and trace elements is also lacking for shrews. In the available literature, reported element concentrations range from means, to geometric means and medians and thus without the raw data it is not always easily comparable across studies (for example; Hickey et al. 2001, Becker et al. 2018, Mina et al. 2019 and the current study). Comparative data for the 23 elements investigated in our study is scant and limited to a handful of studies that will be discussed below to place our findings into a global context. 
Mercury has been reported to have a toxic threshold of $\geq 10 \mathrm{ppm}$ (or $10 \mu \mathrm{g} . \mathrm{g}^{-1}$ ) in hair that indicates adverse health effects such as neurochemical effects and functional behaviour changes in wild mice and captive mink (Wobeser et al. 1976, Burton et al. 1977) and has been accepted to have potential health effects in bats (Becker et al. 2018, Moreno-Brush et al. 2018, Carrasco-Rueda et al. 2020). Mercury contamination in the fur of comparatively few bat species from areas impacted by anthropogenic activities has been investigated. For example, $10 \mu \mathrm{g} \cdot \mathrm{g}^{-1}$ total $\mathrm{Hg}$ in the fur of Myotis lucifugus indicates neurological alterations but lower concentrations of Hg correlate to innate immunity in Desmodus rotundus (Becker et al. 2018). The median levels of $\mathrm{Hg}$ in bat fur reported in our study for molossid bats of $1.27 \mu \mathrm{g} . \mathrm{g}^{-1}$ (range 0.58 $1.95 \mu \mathrm{g} \cdot \mathrm{g}^{-1}$ ) on the Venetia diamond mine and $0.60 \mu \mathrm{g} \cdot \mathrm{g}^{-1}$ (range: $0.39-1.11 \mu \mathrm{g} . \mathrm{g}^{-1}$ ) on Corea Game Farm are well below the concentrations responsible for neurological alterations in M. lucifugus (Becker et al. 2018). Mercury concentrations in the molossid fur in our study are comparable with the range of $\mathrm{Hg}$ reported by other studies as a consequence of a variety of anthropogenic activities (Carrasco-Rueda et al. 2020, Hickey et al. 2001, Becker et al. 2018, Ferrante et al. 2018) but may also reflect background concentrations in the study areas. In south-eastern Amazon, Peru, Carollia perspicillata and Phyllostomus elongatus foraging in the vicinity of artisanal gold mines were shown to have fur Hg concentration medians of $0.66 \mu \mathrm{g} \cdot \mathrm{g}^{-1}$ and $1.90 \mu \mathrm{g} \cdot \mathrm{g}^{-1}$ respectively (Moreno-Brush et al. 2018). Becker et al. (2018) reported dietary guild influenced $\mathrm{Hg}$ concentrations in 22 species of bat from a reserve and forest patch surrounded by agriculture ranging from $0.03 \mu \mathrm{g} . \mathrm{g}^{-1}$ in the frugivore Artibeus intermedius to $145.27 \mu \mathrm{g} \cdot \mathrm{g}^{-1}$ in the carnivorous (predominantly fish eating) bat Noctilio leporinus. Carrasco-Rueda et al. (2020) showed a similar pattern of $\mathrm{Hg}$ contamination in 30 bat species from various dietary guilds impacted by small-scale gold mining with mean $\mathrm{Hg}$ concentrations in all fur samples of $1.33 \pm 0.17 \mu \mathrm{g} . \mathrm{g}^{-1}$. Mercury concentration in fur was shown to be lowest for frugivorous and nectivorous bat species from the family Phyllostomidae (mean range taking into account SD; $0.00-1.45 \mu \mathrm{g} . \mathrm{g}^{-1}$ ), followed in increasing concentrations of Hg in fur by omnivores $\left(0.28-1.33 \mu \mathrm{g} . \mathrm{g}^{-1}\right)$, gleaning insectivores $\left(0.27-2.90 \mu \mathrm{g} . \mathrm{g}^{-1}\right)$ and carnivores $\left(1.32-2.75 \mu \mathrm{g} . \mathrm{g}^{-1}\right)($ Carrasco-Rueda et al. 2020$)$. Aerial insectivores (Vespertilionidae, Molossidae and Emballonuridae) had the highest concentration of Hg in their fur with mean ranges between $1.67-7.86 \mu \mathrm{g} \cdot \mathrm{g}^{-1}$. At these concentrations, the authors suggested that the levels may not pose a health risk and could be due to background concentrations in the environment and not as a result of proximity to gold mining activities or agricultural practices (Carrasco-Rueda et al. 2020). Conversely, $\mathrm{Hg}$ levels in the skin-fur of T. teniotis and Miniopterus schreibersii from the African Quarter of Rome (Italy) reported a low mean concentration of $0.065 \pm 0.031 \mu \mathrm{g} \cdot \mathrm{g}^{-1}$ (Andreani et al. 2019). In Canada (Ontario and Quebec), Hickey et al. (2001) reported high and significantly different concentrations of $\mathrm{Hg}$ in the fur of four species of bats with values that could reflect biomagnification from aquatic prey that develop in $\mathrm{Hg}$ contaminated sediments into top predators (bats). The four bat species were; M. lucifugus (1.3 - 7.6 $\left.\mu \mathrm{g} . \mathrm{g}^{-1}\right)$, M. septentrionalis (geometric mean of $4.4 \mu \mathrm{g} . \mathrm{g}^{-1}$ - max. concentration of $10.2 \mu \mathrm{g} . \mathrm{g}^{-1}$ ), M. leibii septentrionalis (geometric mean of $5.3 \mu \mathrm{g} . \mathrm{g}^{-1}-$ max. concentration of $76.2 \mu \mathrm{g} . \mathrm{g}$ ${ }^{1}$ ) and Eptesicus fuscus (geometric mean of $1.5 \mu \mathrm{g} \cdot \mathrm{g}^{-1}$ - max. concentration of $15.4 \mu \mathrm{g} . \mathrm{g}^{-1}$ ) (Hickey et al. 2001). Wieringa et al. (2020) reported a lower mean $\mathrm{Hg}$ concentration in bat fur than our study, reporting $0.005 \mu \mathrm{g} . \mathrm{g}^{-1}$ in the fur of Lasiurus borealis from across its range in North America which was similar to the concentrations reported for Phyllostomidae bats in Carassco-Rueda et al. (2020). Mean mercury concentrations in M. Iucifiugus fur from two contaminated sites in north-western Virginia (USA) and a reference site in Moscow reported much higher mean concentrations of $118.4 \mu \mathrm{g} . \mathrm{g}^{-1}$ and $3.3 \mu \mathrm{g} . \mathrm{g}^{-1}$ respectively, than that observed in the molossids from our study (Karouna-Renier et al. 2014). The mean concentration observed in the molossids from the mine were appromiately 93 times and 2.6 times lower than the contaminated and reference sites (Karouna-Renier et al. 2014).

Lead in the blood of one individual molossid roosting on the mine had a blood concentration of $0.17 \mu \mathrm{g} \cdot \mathrm{ml}^{-1}$ which is hazardously close to the level of $0.2 \mathrm{ppm} \mathrm{Pb}$ contamination in the blood of an animal (cattle) considered to be lead poisoned (Reis et al. 2010). Additionally, if an animal is suffering from $\mathrm{Pb}$ poisoning, the animal should also be deficient in $\mathrm{Ca}$, Fe and $\mathrm{Zn}$, however, the individual bat of concern had the highest blood concentrations of; Fe $\left(1026.21 \mu \mathrm{g} \cdot \mathrm{ml}^{-1}\right), \mathrm{Ca}\left(0.22 \mu \mathrm{g} \cdot \mathrm{ml}^{-1}\right)$ and $\mathrm{Zn}\left(7.04 \mu \mathrm{g} \cdot \mathrm{ml}^{-1}\right)$ compared to all the other individuals. The implications of this observation is unknown. Elevated levels of $\mathrm{Pb}$ in the fur of bats could be due to $\mathrm{Pb}$ contamination of prey and the physical exposure of bats to vehicular traffic continually entering and exiting the mine throughout the day in close proximity to their roost as seen in $P$. pipstrellus (Flache et al. 2015). In our study, the median $\mathrm{Pb}$ concentrations in the fur of the bats from both sites were similar (control: $0.48 \mu \mathrm{g} . \mathrm{g}^{-1}$, mine: $\left.0.45 \mu \mathrm{g} . \mathrm{g}^{-1}\right)$ (Table 4) and were comparable with median fur concentrations of $M$. myotis in Flache et al. (2015) and Ferrante et al. (2018) of $0.39 \mu g . g^{-1}$ and $0.24-$ $0.29 \mu \mathrm{g} . \mathrm{g}^{-1}$ respectively in mixed environments. Our study presents $\mathrm{Pb}$ concentrations much lower than skin-fur concentrations reported by Andreani et al. (2019) of $36.9 \pm 18.4 \mu \mathrm{g} . \mathrm{g}^{-1}$ in T. teniotis and $M$. schreibersii from Italy. Similarly, the maximum concentrations of Pb reported in our study of $0.936 \mu \mathrm{g} . \mathrm{g}^{-1}$ (mine) and $1.465 \mu \mathrm{g} . \mathrm{g}^{-1}$ (control) are considerably lower than that reported for $N$. nana foraging over wastewater treatment works of $6.187 \mu \mathrm{g} \cdot \mathrm{g}^{-1}$ and $6.951 \mu \mathrm{g} \cdot \mathrm{g}^{-1}$, and from a reference site of $26.609 \mu \mathrm{g} . \mathrm{g}^{-1}$ (Hill et al. 2017).

Of greater concern was the Al recorded in the fur of the molossids in our study were 1.6 up to 23 times higher than the concentrations of Al in fur of M. lucifugus (27- $\left.70 \mu \mathrm{g} . \mathrm{g}^{-1}\right)$ and E. fuscus $\left(4.8 \mu \mathrm{g} . \mathrm{g}^{-1}\right)$ that comparatively were very low (Hickey et al. 2001). Some of the Al values for M. lucifugus fell within the range of values from the mine (43.97 - $\left.185.39 \mu \mathrm{g} . \mathrm{g}^{-1}\right)$. Andreani et al. (2019) reported a mean concentration of $306 \pm 75$ $\mu \mathrm{g} . \mathrm{g}^{-1}$ in skin-fur samples of $T$. teniotis and $M$. schreibersii from a polluted area in Italy (African Quarter of Rome). This mean concentration was higher than the median recorded in our study in bat fur of $102.62 \mu \mathrm{g} \cdot \mathrm{g}^{-1}$ from the control site but lower than the maximum concentration of $558.06 \mu \mathrm{g} . \mathrm{g}^{-1}$ reported at the same site. The median and minimum fur Al level were slightly elevated in the control area but maximum 
concentration recorded from the control area was much higher than in the fur from the mine (Table 4). Aluminum is a non-essential element (Reis et al. 2010) and the range of concentrations in blood and fur of the molossids raises a cause of concern. In rodents, bone concentration of Al $>10$ $\mu \mathrm{g} \cdot \mathrm{g}^{-1}$ has been considered to indicate a reduction in the ability of the animal to excrete $\mathrm{Al}$ or an indication of exposure to high concentrations of $\mathrm{Al}$ (Scheuhammer 1987). Aluminium is known to be toxic to invertebrates and freshwater fishes (van Dam et al. 2018, AL-Taee et al. 2020), neurotoxic to humans as well as causing disturbances in cellular growth, communication and secretory functions, and reductions in bone tissue (Barabasz et al. 2002). There is concern that important metabolic processes in birds and mammals could be negatively affected by Al uptake in environments containing high concentrations of Al (Rosseland et al. 1990) since Al has been shown to negatively affect phosphorous (P) and Ca metabolism resulting in bone abnormalities, weakness of muscle and decreased growth rates (Scheuhammer 1987). Aluminium is a common element in soils (Rosseland et al. 1990) and has been shown to be present in soil dust (8.2\% according to Friedlander 1973) but the percentage that Al contributes to soil dust on the Venetia Diamond Mine and surrounding area is unknown. Future research should investigate whether these concentrations measured in the molossid fur indicate 1) the background levels, 2) a contamination event or 3) have any health implications.

Levels of Fe reported in the fur for the control and mine bats $\left(147.64 \mu \mathrm{g} . \mathrm{g}^{-1}\right.$ and $101.41 \mu \mathrm{g} \cdot \mathrm{g}^{-1}$ respectively) (Table 4) were comparable with the concentration observed in E. fuscus $\left(100.00 \mu \mathrm{g} . \mathrm{g}^{-1}\right)$ in Hickey et al. (2001) and within the ranges reported for $N$. nana (22.501 - $134.097 \mu \mathrm{g} . \mathrm{g}^{-1}$ and 23.798 - $170.52 \mu \mathrm{g} . \mathrm{g}^{-1}$ foraging over wastewater treatment works, and 24.621 - $125.323 \mu \mathrm{g} . \mathrm{g}^{-1}$ from reference sites) (Hill et al. 2017 ). The maximum concentration of $814.00 \mu \mathrm{g} . \mathrm{g}^{-1}$ from an individual from the control site was the highest level reported in fur compared to available literature. Median fur Zn concentrations of 147.09 and $97.7 \mu \mathrm{g} . \mathrm{g}^{-1}$ were similar to the medians and ranges for $M$. nattereri, $M$. bechsteinii, $M$. daubentonii and Plectus auritus studied by Flache et al. (2015 and 2017), and M. lucifugus, M. septentionalis and E. fuscus Hickey et al. (2001). Flache et al. (2015) had noted that M. daubentonii (129.0 $\mu \mathrm{g} . \mathrm{g}^{-1} \mathrm{Zn}$ in fur) is known to forage on chironomid midges emerging from water bodies with contaminated sediment. Perhaps a similar occurrence took place with the molossids opportunistically feeding on emerging adult insects from the mine waste water dam. Perhaps this could explain the observed high Zn concentrations in the fur of the bats from the mine (117.80 $\left.346.4 \mu \mathrm{g} . \mathrm{g}^{-1}\right)$. The ranges of Zn concentrations in our study also overlapped with concentrations reported in Hill et al. (2017) of $247.241-$ $391.349 \mu \mathrm{g} . \mathrm{g}^{-1}, 206.608$ - $554.40 \mu \mathrm{g} \cdot \mathrm{g}^{-1}$ (wastewater treatment works) and $161.907-357.951 \mu \mathrm{g} . \mathrm{g}^{-1}$ (reference sites) although our minimum and maximum ranges were lower (Table 4).

The median As fur concentrations of $0.72 \mu \mathrm{g} \cdot \mathrm{g}^{-1}$ (mine) and $0.26 \mu \mathrm{g} \cdot \mathrm{g}^{-1}$ (control) (Table 4) were low compared to other studies and was comparable to T. teniotis and M. schreibersii skin-fur from a polluted urban area in Italy of $0.29 \pm 0.07 \mu$ g.g ${ }^{-1}$ (Andreani et al. 2019), M. myotis roosting near a petrochemical plant as well as in an uncontaminated area with As fur concentrations of $0.434 \mu \mathrm{g} . \mathrm{g}^{-1}$ and $0.554 \mu \mathrm{g} . \mathrm{g}^{-1}$ respectively (Ferrante et al. 2018). The concentrations of As from the fur of the molossids from the mine were comparable with concentrations reported in fur from $N$. nana foraging over wastewater treatment works $\left(0.588-2.563 \mu \mathrm{g} . \mathrm{g}^{-1}\right.$ and $\left.0.392-1.974 \mu \mathrm{g} . \mathrm{g}^{-1}\right)(\mathrm{Hill}$ et al. 2017$)$. Arsenic is an element of concern as it can crosses the blood-brain barrier and is implicated in neurogenerative diseases (Escudero-Lourdes 2016). Elevated concentrations in bat fur may indicate negative neurological effects in the long-term (Hill et al. 2017). Although significantly different between our two sites, low concentrations of fur Cd were reported for the molossids on the mine and in the control area of 0.09 and $0.02 \mu \mathrm{g} . \mathrm{g}^{-1}$ respectively. These concentrations of $\mathrm{Cd}$ are comparable with $\mathrm{Cd}$ medians of $0.02 \mu \mathrm{g} . \mathrm{g}^{-1}$ in M. Myotis (Ferrante et al. 2018) and $0.06 \mu \mathrm{g} . \mathrm{g}^{-1}$ for Hypsugo savii/Nyctalus leisleiri/Pipistrellus pipistrellus/P. pygmaeus (Mina et al. 2019) and mean concentrations of $0.074 \mu \mathrm{g} . \mathrm{g}^{-1}, 0.119 \mu \mathrm{g} . \mathrm{g}^{-1}$, $0.056 \mu \mathrm{g} . \mathrm{g}^{-1}$ in fur of $N$. nana foraging over two wastewater treatments works and a reference area respectively (Hill et al. 2017 ) and $0.04 \pm 0.008$ $\mu \mathrm{g} . \mathrm{g}^{-1}$ in skin-fur of T. teniotis and M. schreibersii (Andreani et al. 2019). Overall, the values reported in our study overlap with the ranges reported in Hernout et al. (2016b), Flache et al. (2017) and Flache et al. (2015) from a variety of land uses excluding mines. The concentration of Sb in the bat fur from the mine was slightly elevated above the control area (medians $0.18 \mu \mathrm{g} . \mathrm{g}^{-1} \mathrm{vs} 0.04 \mu \mathrm{g} . \mathrm{g}^{-1}$ ) and the opposite was observed for $\mathrm{V}(0.28$ $\mu \mathrm{g} . \mathrm{g}^{-1}$ vs $0.52 \mu \mathrm{g} \cdot \mathrm{g}^{-1}$ ) (Table 4). Both elements were similar to median concentrations recorded for $M$. myotis in Sicily from a polluted area near a petrochemical plant and a control area in Pantalica; Sb: $0.04 \mu \mathrm{g} . \mathrm{g}^{-1}$ and $0.05 \mu \mathrm{g} . \mathrm{g}^{-1}, \mathrm{~V}: 0.30 \mu \mathrm{g} . \mathrm{g}^{-1}$ and $0.43 \mu \mathrm{g} . \mathrm{g}^{-1}$ respectively for the two sites (Ferrante et al. 2018). But were lower than the mean concentration of Sb recorded in skin-fur of T. teniotis and M. schreibersii of $1.98 \pm 1.95 \mu g . g^{-1}$ (Andreani et al. 2019).

In the study by Mina et al. (2019), median fur concentrations of Co $\left(0.34 \mu \mathrm{g} . \mathrm{g}^{-1}\right)$, Ni $\left(2.6 \mu \mathrm{g} . \mathrm{g}^{-1}\right)$, Se $\left(3.42 \mu \mathrm{g} . \mathrm{g}^{-1}\right)$ and Mn $\left(11.37 \mu \mathrm{g} . \mathrm{g}^{-1}\right)$ in $\mathrm{Hypsugo}$ savii/Nyctalus leisleiri, Pipistrellus pipistrellus/P. pygmaeus were most similar to the levels of the molossids from both sites in our study (Co: 0.13 $\mu \mathrm{g} . \mathrm{g}^{-1}$ and $0.24 \mu \mathrm{g} \cdot \mathrm{g}^{-1}$, Ni:1.13 $\mu \mathrm{g} \cdot \mathrm{g}^{-1}$ and $1.38 \mu \mathrm{g} \cdot \mathrm{g}^{-1}$, Se: $5.48 \mu \mathrm{g} \cdot \mathrm{g}^{-1}$ and $4.03 \mu \mathrm{g} . \mathrm{g}^{-1}, \mathrm{Mn}: 4.75 \mu \mathrm{g} \cdot \mathrm{g}^{-1}$ and $13.33 \mu \mathrm{g} \cdot \mathrm{g}^{-1}$ ). Manganese concentrations in the fur of the molossids also fell within the ranges reported for $N$. nana foraging over wastewater treatments works but the maximum concentration reported from the mine in our study $\left(32.61 \mu \mathrm{g} . \mathrm{g}^{-1}\right)$ was $51.5 \%$ lower than the maximum concentration recorded from the reference sites in Hill et al. (2017) of $67.218 \mu \mathrm{g} . \mathrm{g}^{-1}$. Copper concentrations in the molossids fur at both sites of $8.43 \mu \mathrm{g} . \mathrm{g}^{-1}$ and $6.09 \mu \mathrm{g} . \mathrm{g}^{-1}$ were similar again to the values in M. myotis of $5.21 \mu \mathrm{g} \cdot \mathrm{g}^{-1}$ and $7.35 \mu \mathrm{g} \cdot \mathrm{g}^{-1}$ (Ferrante et al. 2018). The ranges of the molossid fur Cu concentrations fell within the ranges reported by Flache et al. (2015), Hernout et al. (2016b), Flache et al. (2017), Hill et al. (2017) and Mina et al. (2019). The median fur concentration of $0.75 \mu \mathrm{g} . \mathrm{g}^{-1}$ of Mo in M. bechsteinii (Flache et al. 2017) was similar to that determined in the molossids from the mine and control area of $0.85 \mu \mathrm{g} \cdot \mathrm{g}^{-1}$ and $0.72 \mu \mathrm{g} \cdot \mathrm{g}^{-1}$ (Table 4). The only comparative data for fur Sn and Rb concentrations in the literature have 
recently been published by Wieringa et al. (2020). Mean fur concentrations of Sn (4.23 ppb) and Rb (0.65 ppb) (Wieringa et al. 2020) were lower than the minimum values recorded from the mine and control area of $0.09 \mu \mathrm{g} . \mathrm{g}^{-1}$ and $0.06 \mu \mathrm{g} . \mathrm{g}^{-1}$ respectively for $\mathrm{Sn}$ and $0.63 \mu \mathrm{g} . \mathrm{g}^{-1}$ and 1.11 $\mu \mathrm{g} . \mathrm{g}^{-1}$ for Rb. Comparative concentrations of Sr are presented in Andreani et al. (2019) with a skin-fur mean concentration of $9.14 \pm 0.60 \mu \mathrm{g} . \mathrm{g}^{-1}$ that is 2.5 and 5 times higher than the maximum concentrations reported in our study in the molossid bats fur from the control site ( $3.65 \mu \mathrm{g} . \mathrm{g}^{-1}$ (median; $\left.1.71 \mu \mathrm{g} \cdot \mathrm{g}^{-1}\right)$ ) and mine area $\left(1.85 \mu \mathrm{g} . \mathrm{g}^{-1}\right.$ (median; $\left.1.44 \mu \mathrm{g} \cdot \mathrm{g}^{-1}\right)$ ). The concentration range of Ba in the fur of the molossids in our study was similar to the minimum value of $1.1 \mu \mathrm{g} \cdot \mathrm{g}^{-1}$ and well below the mean value of $14.8 \mu \mathrm{g} \cdot \mathrm{g}^{-1}$ in all types of tissue of insectivorous bats (Zukal et al. 2015)

Finally, Cr levels in the molossids in our study of $0.99 \mu \mathrm{g} \cdot \mathrm{g}^{-1}$ in bats from the control area and $1.07 \mu \mathrm{g} . \mathrm{g}^{-1}$ from the diamond mine were lower than the median concentration of $2.52 \mu \mathrm{g} . \mathrm{g}^{-1}$ (range: $0.82-8.67 \mu \mathrm{g} \cdot \mathrm{g}^{-1}$ ) in Hypsugo savii/Nyctalus leisleiri/Pipistrellus pipistrellus/P. pygmaeus on wind farms in Portugal (Mina et al. 2019) but similar to median concentrations of and $0.87 \mu \mathrm{g} . \mathrm{g}^{-1}$ and $0.99 \mu \mathrm{g} . \mathrm{g}^{-1}$ in $\mathrm{M}$. myotis respectively from a control area and an area near a petrochemical plant, Sicily (Ferrante et al. 2018). Similarly, the molossid fur concentrations of Cr fell within the ranges reported for $N$. nana captured over wastewater treatment works and reference sites in South Africa (Hill et al. 2017). The concentration of $\mathrm{Cr}$ that would be considered harmful in bats is unknown but elevated levels of $\mathrm{Cr}$ and other heavy metals $(\mathrm{Cu}, \mathrm{Cd}, \mathrm{Zn}$ and $\mathrm{Pb})$ in the liver and kidneys in the shrew Crocidura russula from a landfill site in Garraf (Spain) of $3.49 \pm 0.45 \mu \mathrm{g} . \mathrm{g}^{-1}$ and $5.40 \pm 0.59 \mu \mathrm{g} . \mathrm{g}^{-1}$ respectively were suggested to have negative health implications (Sánchez-Chardi et al. 2007). Currently, there are no comparable studies for the bat fur concentrations of $\mathrm{B}$ and $\mathrm{K}$ with other bat or small mammal species, thus the interpretation and potential health impacts of these element concentrations remains unknown.

Data are scant concerning heavy metal and trace element levels in small mammal blood for an adequate comparison with the current data. Karouna-Renier et al. (2014) investigated the effects of Hg concentrations on mtDNA in M. lucifugus collected from contaminated sites from South (Grottoes) and North (Mt. Sydney) Rivers in north-western Virginia, USA and a reference site in Moscow, Russia. Myotis lucifugus from the contaminated sites (particularly Mt. Sydney) revealed significantly higher levels of mtDNA damage than those from the reference area. The mean $\mathrm{Hg}$ concentration in the blood from the molossids from the mine in our study was comparable with the concentration reported from Moscow by

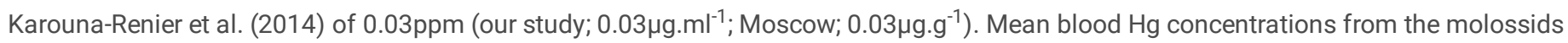
collected from our control site was notably lower than the reference and contaminated sites reported by Karouna-Renier et al. (2014). Thus the health effects of the concentrations of $\mathrm{Hg}$ recorded in our study are probably negligible. A study on whole bat samples (Smith and Rongstad 1982) investigating $\mathrm{Zn}, \mathrm{Cu}, \mathrm{Cd}, \mathrm{Pb}$ and Ni concentrations in bats from a proposed mining site and an active mine near Timmins, Ontario, Canada revealed heavy metal concentrations much higher than those recorded in the blood from the molossids in our study. Heavy metals are known to accumulate in internal organs and tissues (Naidoo et al. 2016) thus the whole bat sample would have much higher concentrations than the blood samples, but we use it as a proxy none-the-less. With the exception of Fe and Zn, the reported heavy metal and trace element values in the blood of the molossids may reflect the background conditions, future research in this area is critical to establish baseline reference data in South Africa.

The only available literature concerning heavy metals in South African bats was published by Naidoo et al $(2013,2014,2016)$ and Hill et al. (2016). Naidoo et al. (2013, 2015 and 2016) reported that an urban adapter bat species, the Banana bat (Neoromicia nana), foraging over waste water treatment works may suffer from chronic health problems associated with bioaccumulation of heavy metals. Bioaccumulation of heavy metals in $N$. nana could have been through the consumption of Diptera (possibly chironomid midges that are tolerant of the polluted water bodies) swarming over the waste water sites (Naidoo et al. 2013). The heavy metal concentrations reported could have been responsible for the observed damage to the kidneys (including enlarged kidneys that indicated nephrotoxicity) and liver that are responsible for detoxifying pollutants (Naidoo et al. 2016). Even at low concentrations, $\mathrm{Ni}, \mathrm{Cd}$ and $\mathrm{Pb}$ inhibit proteins that are involved in DNA repair which may have accounted for the significant DNA damage noted in N. nana (Naidoo et al. 2015). Additionally, Hill et al. (2016) provided evidence of changes in the profile of fatty acids in brown adipose tissue of $N$. nana foraging over wastewater treatment works. These changes have the potential to affect the use of torpor, mitochondrial functioning and energy use (Hill et al. 2016).

\section{Implications for bat conservation.}

In addition to the global stressors that bats already face, namely habitat loss, changes in available resource quantity and quality, climate change, increasing number of wind turbines, disease pressure (de Souza et al. 2020, Lawson et al. 2020, Flache et al. 2018, Hernout et al. 2016a) and environmental pollution including organophosphates (Bayat et al. 2014), it is vital that both the origin of elements and the toxicological response of bats is understood. This knowledge will assist conservation authorities and specialists to make informed decisions concerning bat conservation and mitigation strategies within the context of looming anthropogenic developments and conservation areas. For example, we may find that in accordance with legislation and mine protocols that the current specifications for the containment of waste water can still expose ecosystems to elevated concentrations of elements. Bat fur used as a biomarker could indicate bioaccumulation of elements either through directly drinking from the waste water dams or feeding on emerging adult insects with an aquatic development phase within the waste water dams. The shortfall with the current available literature is that we still do not know; 1 ) the specific toxicological thresholds for numerous bat species, 2) the physiological and resulting ecological effects of these elements and 3) whether there are phylogenetic responses to elements (e.g.

Page $9 / 20$ 
Total mercury concentrations in fur has been shown to have a strong phylogenetic signal as reported by Becker et al. (2018)). Southern hemisphere bat species have been poorly studied in this regard. Additionally, there is a lack of long-term and recapture studies on the impact of heavy metals and trace elements on bat populations that include the effects of age and gender (Hernout et al. 2016b).

\section{Conclusion}

Our study is the first in South Africa to provide some data on heavy metal and trace element concentrations in blood and fur of $M$. condy/urus and T. aegyptiaca roosting on the Venetia Diamond Mine and in a control area. Bats do demonstrate some potential as suitable bioindicators for the monitoring of ecosystem health over and near opencast mining operations using non-lethal and non-invasive methods. However, only four out of the 22 elements tested in the fur and blood were significantly different between the bats roosting on mine and those from the control area namely; B, K, Rb and Cd (fur) and Mn, Zn, Sb and $\mathrm{Hg}$ (blood).

The concentrations of the elements reported in our study could reflect the natural background levels and may not necessarily be a cause of concern at this point in time. However, this may fluctuate during the year and the impacts of these elements on the organs and bones of bats may reveal another story. We could not investigate the heavy metal and trace element contamination of other bat species, as comparative individuals were not captured, thus we do not know the impact of the mining activity on many other bat species known to occur in the area. Future investigation is required in this regard.

Tadarida aegyptiaca and $M$. condylurus belong to the family Molossidae and are similar from an ecological and morphological perspective (masses and forearm lengths not significantly different; $P=0.30$ and $P=0.21$ respectively) thus we do not expect a phylogenetic effect of heavy metal and trace element concentrations of the fur and blood. Body size and mass probably did not play a role in the resulting differences in elemental concentrations between the individuals captured on the Venetia diamond mine and Corea Game Farm.

We have but a mere glimpse into how acute and chronic exposure of heavy metals and trace elements affect bats. There is an exciting opportunity for much needed research to bridge the gap in our knowledge with regards to collecting baseline levels of elements in bat fur, investigating correlations between internal and external tissue/organ elemental concentrations, understanding how these elements physiologically interact in different bat species and the bat specific toxic thresholds of these elements. Significantly higher levels of elements in fur than blood (as reported in our study) may not necessarily indicate that a bat is suffering from toxicological effects of the elements. Using bat fur as a reliable less-invasive biological marker has potential to indicate a degree of environmental contamination (Hernout et al. $2016 a$ \& b). A cautionary proposal can only be given at this point in time that the elevated concentrations of some elements in the fur samples could indicate which elements persist in the environment. These elements may be a cause of concern for the local bat communities and their consequent conservation. The data presented here should be used with caution and can be regarded as the first baseline data for two species of molossid bats in northern Limpopo, South Africa.

As anthropogenic activities, particularly mining operations continue to liberate metals, trace elements and chemicals into the environment, these substances become available for assimilation into the food chain, where individual animal health and ecosystem resilience can be negatively impacted, especially when physiological damage is incurred. Understanding how elements and chemicals are made available during opencast diamond mining and the impacts of such will determine how these impacts could potentially be managed and how these impacts will affect local animal populations and their inherent conservation.

\section{References}

Aggett PJ (1985) Physiology and metabolism of essential trace elements: an outline. Clinic in Endocrinology and Metabolism 14:513- 543.

Ali H, Khan E, llahi I (2019) Environmental chemistry and ecotoxicology of hazardous heavy metals: environmental persistence, toxicity, and bioaccumulation. Journal of Chemistry 4:1-14. https://doi.org/10.1155/2019/6730305.

AL-Taee SK, Karam H, Ismail, HK (2020) Review on some heavy metals toxicity on freshwater fishes. Journal of Applied Veterinary Sciences 5:7886. https://dx.doi.org/10.21608/javs.2020.100157.

Andreani G, Canavacciuolo A, Menotta S, Spallucci V, Fedrizzi G, Carpenè E, Isani G (2019) Environmental exposure to non-essential trace elements in two bat species from urbanised (Tadarida teniotis) and open land (Miniopterus schreibersii) areas in Italy. Environmental Pollution 254:113034. https://doi.org/10.1016/j.envpol.2019.113034.

Bánfalvi G (2011) Cellular effects of heavy metals. Bánfalvi G (ed.). Springer Science and Business Media B. V. https://doi.org/10.1007/978-94007-0428-2_1.

Barabasz W, Albińska D, Jaśkowska M, Lipiec J (2002) Ecotoxicology of Aluminium. Polish Journal of Environmental Studies 11:199-203. 
Bat L, Ahmed Q, Öztekin A, Arici E (2020) A review on heavy metal levels in sea cucumbers. International Journal of Environment and Geoinformatics 7:252-264. https://doi.org/10.30897/ijegeo.734402.

Bayat S, Geiser F, Kristiansen P, Wilson SC (2014) Organic contaminants in bats: Trends and new issues. Environmental International 63 : 40 - 52. http://dx.doi.org/10.1016/j.envint.2013.10.009.

Becker DJ, Chumchal MM, Broders HG, Korstian JM, Clare EL, Rainwater TR, Platt SG, Simmons NB (2018) Mercury bioaccumulation in bats reflects dietary connectivity to aquatic food webs. Environmental Pollution 233:1076-1085. https://doi.org/10.1016/j.envpol.2017.10.010.

Beyersmann D, Hartwig A (2008) Carcinogenic metal compounds: recent insight into molecular and cellular mechanism. Archives of Toxicology 82:493-512. https://doi.org/10.1007/s00204-008-0313-y.

Brown RJ, Tait M, Field M (2009) Geology of a complex kimberlite pipe (K2 pipe, Venetia Mine, South Africa): Insights into conduit processes during explosive ultrabasic eruptions. Bulletin of Volcanology 71:95-112. https://doi.org/10.1007/s00445-008-0211-4.

Burton GV, Alley RJ, Rasmussen GL, Orton P, Cox V, Jones P, Graff D (1977) Mercury and behaviour in wild mouse populations. Environmental Research 14:30-34.

Carrasco-Rueda F, Loiselle BA, Frederick PC (2020) Mercury bioaccumulation in tropical bats from a region of active and small-scale gold mining. Ecotoxicology 29: 1302-1042. https://doi.org/10.1007/s10646-020-02195-3.5.

Clark DR, Shapiro Wenner A, Moore JF (1986) Metal residues in bat colonies, Jackson County, Florida, 1981-1983. Florida Field Naturalist 14:3845.

Dallinger R (1994) Invertebrate organisms as biological indicators of heavy metal pollution. Applied Biochemistry and Biotechnology 48:27-31. https://doi.org/10.1007/BF02825356.

de Souza MB, de Souza Santos LR, Borges RE, Nunes HF, Vieira TB, Pacheco SM, de Melo e Silva D (2020) Current status of ecotoxicological studies of bats in Brazil. Bulletin of Environmental Contamination and Toxicology 104:393-399. https://doi.org/10.1007/s00128-020-02794-0.

Denloye AA, Abdulsalam L, Bakre S, Ajelara O, Olowu R (2015) Heavy metals in some termite species and their nests in Ojo, Lagos, Nigeria. Animal Research International 12:2178-2183.

Dragun Z, Tepić N, Ramani S, Krasnići N, Marijić VF, Valić D, Kapetanović D, Erk M, Rebok K, Kostov V, Jordanova M (2019) Mining waste as a cause of increased bioaccumulation of highly toxic metals in liver and gills of Vardar chub (Squalis vararensis Karaman, 1928). Environmental Pollution 247:564-576. https://doi.org/10.2026/j.envpol.2019.01.068.

Egwumah FA, Egwumah PO, Edet DI (2017) Paramount roles of wild birds as bioindicators of contamination. International Journal of Avian \& Wildlife Biology 6:00041. https://doi.org/10.15406/ijawb.2017.02.00041

Escudero-Lourdes C (2016) Toxicity mechanisms of arsenic that are shared with neurodegenerative diseases and cognitive impairment: Role of oxidative stress and inflammatory responses. NeuroToxicology 53:223-235. https://doi.org/10.1016/j.neuro.2016.02.002.

Ferrante M, Spena MT, Hernout BV, Grasso A, Messina A, Grasso R, Agnelli P, Brundo MV, Copat C (2018) Trace elements bioaccumulation in liver and fur of Myotis myotis from two caves of the eastern side of Sicily (Italy): A comparison between a control and polluted area. Environmental Pollution 210:273-285. https://doi.org/10.1016/j.envpol.2018.04.133

Flache L, Becker NI, Kierdorf U, Czarnecki S, Düring R, Encarnação JA (2015) Hair samples as monitoring units for assessing metal exposure of bats: a new tool for risk assessment. Mammalian Biology 80:178-181. https://doi.org/10.1016/j.mambio.2015.01.007.

Flache L, Becker NI, Kierdorf U, Czarnecki S, Düring R, Encarnação JA (2018) Similar but not the same: metal concentrations in hair of three ecologically similar, forest-dwelling bat species (Myotis bechsteinii, Myotis nattereri, and Plecotus auritus). Environmental Science and Pollution Research 25:5437-5446. https://doi.org/10.1007/s11356-017-0884-3.

Fraser EE, Longstaffe FJ, Fenton MB (2013) Moulting matters: the importance of understanding moulting cycles in bats when using fur for endogenous marker analysis. Canadian Journal of Zoology 91:533-544. https://doi.org/10.1139/cjz-2013-0072.

Friedlander SK (1973) Chemical element balances and identification of air pollution sources. Environmental Science \& Technology 7: 235240. https://doi.org/10.1021/es60075a005. 
Gall JE, Boyd RS, Rajakaruma N (2015) Transfer of heavy metals through terrestrial tood webs: a review. Environ. Monit. Assess. $187: 201$. https://doi.org/10.1007/s10661-015-4436-3.

Garrett RG (2000) Natural sources of metals to the environment. Human and Ecological Risk Assessment 6:945-963.

https://doi.org/10.1080/10807030091124383.

Griffiths SR, Donato DB, Coulson G, Lumsden LF (2014) High levels of activity of bats at gold mining water bodies: 1 implications for compliance with the International Cyanide Management Code. Environmental Science and Pollution Research 21:7263-7275.

https://doi.org/10.1007/s11356-014-2651-z.

Harding LE, Harris ML, Elliott JE (1998) Heavy and trace metals in wild mink (Mustela vison) and River Otter (Lontra Canadensis) captured on rivers receiving metals discharges. Bulletin of Environmental Contamination and Toxicology 61:600-607.

Hernout BV, Arnold KE, McClean CJ, Walls M, Baxter M, Boxall ABA (2016a) A national level assessment of metal contamination in bats. Environmental Pollution 214:847-858. http://dx.doi.org/10.1016/j.envpol.2016.04.079.

Hernout BV, McClean CJ, Arnold KE, Walls M, Baxter M, Boxall ABA (2016b) Fur: a non-invasive approach to monitor heavy metal exposure in bats. Chemosphere 147:376-381. http://dx.doi.org/10.1016/j.chemosphere.2015.12.104.

Hickey MBC, Fenton MB, MacDonald KC, Soulliere C (2001) Trace elements in the fur of bats (Chiroptera: Vespertilionidae) from Ontario and Quebec, Canada. Bulletin of Environmental Contamination and Toxicology 66:699-706. https://doi.org/10.1007/s00128-001-0065-3.

Hill K, van Aswegen S, Schoeman MC, Claassens S, Jansen van Rensburg P, Naidoo S, Vosloo D (2016) Foraging at wastewater treatment works affects brown adipose tissue fatty acid profiles in banana bats. Biology Open 0:1-8. https:/doi.org/10.1242/bio.013524.

Hill K, Schoeman MC, Vosloo D (2017) The brains of bats foraging at wastewater treatment works accumulate arsenic, and have low nonenzymatic antioxidant capacities. NeuroToxicology 69:232-241. https://doi.org/10.1016/j.neuro.2017.12.004.

Idowu, A. B., Ademolu KO, Bamidele JA (2014) Nutrition and heavy metal levels in the mound termite, Macrotermes bellicosus (Smeathman) (Isoptera: Termitidae), at three sites under varying land use in Abeokuta, Southwestern Nigeria. African Entomology 22:156-162.

http://dx.doi.org/10.4001/003.022.0119.

Jakimska, A., Konieczka, P., Skóra, K. and Namieśnik, J. 2011. Bioaccumulation of metals in tissues of marine animals, Part 1: the role and impact of heavy metals on organisms. Polish Journal of Environmental Studies 20: 1117 - 1125.

Jones G, Jacobs DS, Kunz TH, Willig MR, Racey P (2009) Carpe noctem: the importance of bats as bioindicators. Endangered Species Research 8:93-115. https://doi.org/10.3354/esr00182.

Karouna-Renier NK, White C, Perkins CR, Schmerfeld JJ, Yates D (2014) Assessment of mitochondrial DNA damage in little brown bats (Myotis lucifugus) collected near a mercury-contaminated river. Ecotoxicology 23:1419-1429. https://10.1007/s10646-014-1284-9.

Kasso M, Balakrishnan M (2013) Ecological and economic importance of bats (order Chiroptera). ISRN Biodiversity 2013:1-9.

Kim R-Y, Yoon J-K, Kim T-S, Yang J, Owens G, Kim K (2015) Bioavailability of heavy metals in soils: definitions and practical implementation - a critical review. Environmental Geochemistry and Health 37:1041-1061. https://doi.org/10.1007/s10653-015-9695-y.

Kolarova N, Napiórkowski, P (2021) Trace elements in aquatic environment. Origin, distribution, assessment and toxicity effect for the aquatic biota. In Press. https://doi.org/10.1016/j.ecohyd.2021.02.002.

Kunz TH, Whitaker JO (1983) An evaluation of fecal analysis for determining food habits of insectivorous bats. Canadian Journal of Zoology 61:1317-1321.

Lawson M, Jenne D, Thresher R, Houck D, Wimsatt J, Straw B (2020) An investigation into the potential for wind turbines to cause barotrauma in bats. PLoSONE 45:e0242485. https://doi.org/10.1371/journal.pone.0242485

Lovett JJ, McBee K (2015) Possible alteration of circadian rhythms in bats at a heavy metal contaminated site. Proceedings of the Oklahoma Academy of Science $95: 71-78$.

Mansour SA, Soliman SS. Soliman KM (2016) Monitoring of heavy metals in the environment using bats as bioindicators: first study in Egypt. Vespertilio 18: 61 - 78.

Page $12 / 20$ 
Mina R, Alves J, Alves de Silva A, Natal-da-Luz T, Cabral JA, Barros P, Topping CJ, Sousa JP (2019) Wing membrane and fur samples as reliable biological matrices to measure bioaccumulation of metals and metalloids in bats. Environmental Pollution 253:199-206. https://doi.org/10.1016/j.envpol.2019.06.123.

Monadjem A, Taylor PJ, Cotterill FPD, Schoeman MC (2020) Bats of Southern and Central Africa. $2^{\text {nd }}$ Edition. Wits University Press, Johannesburg. http://dx.doi.org.10.18772/22020085829.

Moreno-Brush M, Portillo A, Brändel SD, Storch I, Tschapka M, Biester H (2018) Mercury concentrations in bats (Chiroptera) from a gold mining area in the Peruvian Amazon. Ecotoxicology 27:45-54. https://doi.org/10.1007/s10646-017-1869-1.

Mucina L, Rutherford MC (eds.). (2011) The vegetation of South Africa, Lesotho and Swaziland. Strelitiza 19. South African National Biodiversity Institute, Pretoria.

Nagajyoti PC, Lee KD, Sreekanth TVM (2010) Heavy metals, occurrence and toxicity for plants: a review. Environmental Chemistry Letters 8:199206. https://doi.org/10.1007/s10311-010-0297-8.

Naidoo S, Vosloo D, Schoeman MC (2013) Foraging at wastewater treatment works increases the potential for metal accumulation in an urban adapter, the banana bat (Neoromicia nana). African Zoology 48:39-55. https://doi.org/10.1080/15627020.2013.11407567.

Naidoo S, Vosloo D, Schoeman MC (2015) Haematological and genotoxic responses in an urban adapter; the banana bat, foraging at wastewater treatment works. Ecotoxicology and Environmental Safety 114:304-311. http://dx.doi.org/10.1016/j.ecoenv.2014.04.043.

Naidoo S, Vosloo D, Schoeman MC (2016) Pollutant exposure at wastewater treatment works affects the detoxification organs of an urban adapter, the banana bat. Environmental Pollution 208:830-839. http://dx.doi.org/10.1016/j.envpol.2015.09.056.

Obrist D, Kirk JL, Zhang L, Sunderland EM, Jiskra M, Selin NE (2018) A review of global environmental mercury processes in response to human and natural perturbations: changes of emission, climate and land use. Ambio 47:116-140. https://doi.org/10.1007/s13280-017-1004-9.

Picker M, Griffiths C, Weaving A (2004) Insects of South Africa. Struik Publishers, Cape Town.

Pikula J, Zukal J, Adam V, Bandouchova H, Beklova M, Hajkova P, Horakova J, Kizek R, Valentikova L (2010) Heavy metals and metallothionein in vespertilionid bats foraging over aquatic habitats in the Czech Republic. Environmental Toxicology and Chemistry 29:501-506.

https://doi.org/10.1002/etc.80.

Powolny, T., Scheifler, R., Roaul, F. and Fritsch. 2019. Is blood a reliable indicator of trace metal concentrations in organs of small mammals? Chemosphere 217: 320 - 328. https://doi.org/10.1016/j.chemosphere.2018.10.2515.

Reis, L. S. L., Pardo, P. E., Camargos, A. S. and Oba, E. 2010. Mineral element and heavy metal poisoning in animals. Journal of Medicine and Medical Sciences 1: $560-579$.

Riccucci M, Lanza B (2014) Bats and insect pest control: a review. Vespertilio 17:161-69.

Rosseland BO, Eldhuset TD, Staurnes M (1990) Environmental effects of aluminium. Environmental Geochemistry and Health 12:17-27. https://doi.org/10.1007/BF01734045.

Russo D, Jones G (2015) Bats as bioindicators: an introduction. Mammalian Biology 80:157-162.

https://doi.org/10.1016/j.mambio.2015.03.005.

Sánchez-Chardi A, Nadal J (2007) Bioaccumulation of metals and effects of landfill pollution in small mammals. Part 1. The greater whitetoothed shrew, Crocidura russula. Chemosphere 68:703-711. https://doi.org/10.1016/j.chemosphere.2007.01.042.

Sánchez-Chardi A, Peñarroja-Matutano C, Oliveira Ribeiro CA, Nadal J (2007) Bioaccumulation of metals and effects of landfill pollution in small mammals. Part 2. The wood mouse, Apodemus sylvaticus. Chemosphere 70:101-109. https://doi.org/10.1016/j.chemosphere.2007.01.042.

Scheuhammer AM (1987) The chronic toxicity of aluminium, cadmium, mercury and lead in birds: A review. Environmental Pollution 46:263-295.

Smith GJ, Rongstad OJ (1982) Small mammal heavy metal concentrations from mined and control sites. Environmental Pollution (Series A) 28:121-134.

Smith CS, de Jong CE, Field HE (2010) Sampling small quantities of blood from microbats. Acta Chiropterologica 12:255-258. https://doi.org/10.3161/150811010X504752. 
Taylor PJ, Lim BK, Pennay M, Soisook P, Loureiro LO, Moras LM, Kingston T (2019) Family Molossidae (Free-tailed bats). Pp. 598 - 675 in: Wilson, D. E. and Mittermeier, R. A. eds. 2019. Handbook of the Mammals of the World, vol 9. Bats, Lynx Edicions, Barcelona.

Tchounwou PB, Yedjou CG, Patlolla AK, Sutton DJ (2012) Heavy Metal Toxicity and the Environment. Molecular, Clinical and Environmental Toxicology 101:133-164. https://doi.org/10.1007/978-3-7643-8340-4_6

van Dam JW, Trenfield MA, Streten C, Harford AJ, Parry D, van Dam RA (2018) Assessing chronic toxicity of aluminium, gallium and molybdenum in tropical marine waters using a novel bioassay for larvae of the hermit crab Coenobita variabilis Ecotoxicology and Environmental Safety 165:349-356. https://doi.org/10.1016/j.ecoenv.2018.09.025.

Wieringa JG, Nagel J, Nelson DM, Carstens BC, Gibbs HL (2020) Using trace elements to identify the geographic origin of migratory bats. PeerJ 8:e10082. https://dx.doi.org/10.7717\%2Fpeerj.10082.

Wobeser G, Nielsen NO, Schiefer B (1976) Mercury and Mink II. Experimental methyl mercury intoxication. Canadian Journal of Comparative Medicine 40:34-45.

Zocche JJ, Leffa DD, Damiani AP, Carvalho F, Mendonça RA, dos Santos CEI, Boufleur LA, Dias JF, de Andrade, VM (2010) Heavy metal and DNA damage in blood cells of insectivore bats in coal mining areas of Catarinse coal basin, Brazil. Environmental Research 110:684-691. https://doi.org/10.1016/j.envres.2010.06.003.

Zukal J, Pikula J, Bandouchova H (2015) Bats as bioindicator of heavy metal pollution: History and prospect. Mammalian Biology 80:220-227. https://doi.org/10.1016/j.mambio.2015.01.001.

\section{Tables}

Table 1. The classification of elements tested for in the blood and fur of bats based on the classification in Bánfalvi 2011. Each element is determined to be a heavy metal if its density is $\geq 3 \mathrm{mg} \cdot \mathrm{g}^{-1}$ and is a trace element if it occurs naturally in low concentrations and is required in low concentrations by an organism for biological function, development and repair. Elements marked with " $\star$ " indicate their presence in animal and plant cells but their biological importance is largely unknown. 


\begin{tabular}{|c|c|c|c|}
\hline Element & Density of Element $\left(\mathrm{g} \cdot \mathrm{cm}^{3}\right)$ & Heavy Metal & Trace Element \\
\hline Antimony (Sb) & 6.697 & $x$ & $x$ \\
\hline Aluminum (Al) & 2.7 & & * \\
\hline Arsenic (As) & 5.727 & $x$ & * \\
\hline Barium (Ba) & 3.51 & $x$ & * \\
\hline Boron (B) & 2.46 & & $x$ \\
\hline Calcium (Ca) & 1.55 & & $x$ \\
\hline Cadmium (Cd) & 8.65 & $x$ & * \\
\hline Chromium (Cr) & 7.19 & $x$ & $x$ \\
\hline Cobalt (Co) & 8.9 & $x$ & $x$ \\
\hline Copper (Cu) & 8.96 & $x$ & $x$ \\
\hline Iron (Fe) & 7.874 & $x$ & $x$ \\
\hline Lead $(\mathrm{Pb})$ & 11.34 & $x$ & * \\
\hline Manganese (Mn) & 7.47 & $x$ & $x$ \\
\hline Mercury $(\mathrm{Hg})$ & 13.534 & $x$ & * \\
\hline Molybdenum (Mo) & 10.28 & $x$ & $\mathrm{X}$ \\
\hline Nickel (Ni) & 8.908 & $x$ & $x$ \\
\hline Potassium (K) & 0.856 & & $x$ \\
\hline Rubidium (Rb) & 1.532 & & * \\
\hline Selenium (Se) & 4.819 & $x$ & $x$ \\
\hline Strontium (Sr) & 2.63 & & * \\
\hline $\operatorname{Tin}(S n)$ & 7.31 & $x$ & $x$ \\
\hline Vanadium (V) & 6.11 & $x$ & $x$ \\
\hline Zinc (Zn) & 7.14 & $x$ & $x$ \\
\hline
\end{tabular}

Table 2. Selected individuals of Mops condylurus and Tadarida aegyptiaca captured during summer (December 2018) from the Venetia diamond mine (VDM) and Corea Game Farm (CGF) with their associated measurements and faecal pellet analysis data. 


\begin{tabular}{|c|c|c|c|c|c|c|c|c|c|}
\hline \multirow[b]{2}{*}{$\begin{array}{l}\text { Location } \\
\text { (Bat Code) }\end{array}$} & \multirow[b]{2}{*}{ Gender } & \multirow[b]{2}{*}{ Forearm } & \multirow[b]{2}{*}{ Mass } & \multirow[b]{2}{*}{$\begin{array}{l}\text { Species (\# of } \\
\text { faecal pellets) }\end{array}$} & \multicolumn{5}{|c|}{ Percentage volume of insect order (Family/Suborder) } \\
\hline & & & & & $\begin{array}{l}\text { Isoptera } \\
\text { (Termitidae) }\end{array}$ & $\begin{array}{l}\text { Hymenoptera } \\
\text { (Formicidae) }\end{array}$ & Coleoptera & Lepidoptera & $\begin{array}{l}\text { Hemiptera } \\
\text { (Heteroptera) }\end{array}$ \\
\hline $\begin{array}{l}\text { VDM } \\
\text { (DCT024) }\end{array}$ & Male & 47.11 & 21.50 & $\begin{array}{l}\text { M. condylurus } \\
(n=1)\end{array}$ & 100 & - & - & - & - \\
\hline $\begin{array}{l}\text { VDM } \\
\text { (DCT025) }\end{array}$ & Male & 47.13 & 23.00 & $\begin{array}{l}\text { M. condylurus } \\
(\mathrm{n}=2)\end{array}$ & 100 & - & - & - & - \\
\hline $\begin{array}{l}\text { VDM } \\
\text { (DCT029) }\end{array}$ & Female & 43.99 & 18.00 & $\begin{array}{l}\text { M. condylurus } \\
(n=2)\end{array}$ & 100 & - & - & - & - \\
\hline $\begin{array}{l}\text { VDM } \\
\text { (DCT033) }\end{array}$ & Male & 46.90 & 23.00 & $\begin{array}{l}\text { M. condylurus } \\
(\mathrm{n}=2)\end{array}$ & 100 & - & - & - & - \\
\hline $\begin{array}{l}\text { VDM } \\
\text { (DCT034) }\end{array}$ & Female & 46.22 & 20.00 & $\begin{array}{l}\text { M. condylurus } \\
(n=1)\end{array}$ & 100 & - & - & - & - \\
\hline $\begin{array}{l}\text { VDM } \\
\text { (DCT035) }\end{array}$ & Male & 49.82 & 26.00 & $\begin{array}{l}\text { M. condylurus } \\
(n=3)\end{array}$ & 100 & - & - & - & - \\
\hline $\begin{array}{l}\text { CGF } \\
\text { (DCT049) }\end{array}$ & Female & 46.58 & 18.00 & $\begin{array}{l}\text { T. aegyptiaca } \\
(\mathrm{n}=4)\end{array}$ & 99 & 1 & - & - & - \\
\hline $\begin{array}{l}\text { CGF } \\
\text { (DCT051) }\end{array}$ & Female & 47.91 & 19.50 & $\begin{array}{l}\text { T. aegyptiaca } \\
(\mathrm{n}=4)\end{array}$ & 100 & - & - & - & - \\
\hline $\begin{array}{l}\text { CGF } \\
\text { (DCT052) }\end{array}$ & Female & 48.54 & 18.50 & $\begin{array}{l}\text { T. aegyptiaca } \\
(\mathrm{n}=1)\end{array}$ & 100 & - & - & - & - \\
\hline $\begin{array}{l}\text { CGF } \\
\text { (DCT066) }\end{array}$ & Female & 45.83 & 22.00 & $\begin{array}{l}\text { M. condylurus } \\
(n=1)\end{array}$ & - & - & - & 90 & 10 \\
\hline $\begin{array}{l}\text { CGF } \\
\text { (DCT070) }\end{array}$ & Female & 48.06 & 24.50 & $\begin{array}{l}\text { T. aegyptiaca } \\
(\mathrm{n}=1)\end{array}$ & - & - & 99.5 & - & 0.5 \\
\hline
\end{tabular}

Table 3. Summary of the statistical analyses $P$-values and associated statistical test since not all of the data sets were normally distributed. Where both data sets were not normally distributed, Mann-Whitney U-test was performed ${ }^{(a}$ ), where both data sets were normally distributed, anovas were used $\left({ }^{b}\right)$ and where one data set was normally distributed and the other was not, t-tests assuming unequal variances were run $\left({ }^{c}\right)$. CGF = control site; Corea Game Farm; VDM = Venetia Diamond Mine. 


\begin{tabular}{|c|c|c|c|}
\hline & Fur & Blood & Total \\
\hline Element & CGF VDM & CGF VDM & Fur Blood \\
\hline B & $0.004^{a}$ & $0.96^{\mathrm{b}}$ & $0.0001^{c}$ \\
\hline $\mathrm{Al}$ & $0.46^{c}$ & $0.75^{\star a}$ & $6.0 e-05^{\star a}$ \\
\hline $\mathrm{K}$ & $0.02^{b}$ & $0.86^{b}$ & $0.46^{b}$ \\
\hline $\mathrm{Ca}$ & $0.93^{c}$ & $0.22{ }^{* c}$ & $3.0 \mathrm{e}-06^{\mathrm{a}}$ \\
\hline V & $0.69 * b$ & $0.73^{a}$ & $2.0 \mathrm{e}-06^{\star a}$ \\
\hline $\mathrm{Cr}$ & $0.06^{b}$ & $0.58 * c$ & 0.0001 *a \\
\hline $\mathrm{Mn}$ & $0.56^{b}$ & $0.02 * c$ & $3.0 \mathrm{e}-06^{\mathrm{a}}$ \\
\hline $\mathrm{Fe}$ & $0.26^{c}$ & $0.92^{b}$ & $3.8 \mathrm{e}-06^{c}$ \\
\hline Co & $0.80 * b$ & $0.44 \star^{\mathrm{c}}$ & $0.002 \star c$ \\
\hline $\mathrm{Ni}$ & $0.76^{c}$ & 0.34 *a & $2.0 e-6^{a}$ \\
\hline $\mathrm{Cu}$ & $0.24^{a}$ & $0.29^{b}$ & $0.001^{c}$ \\
\hline $\mathrm{Zn}$ & $0.19^{c}$ & $0.01^{c}$ & $0.37^{b}$ \\
\hline As & $0.81^{b}$ & $0.37 * b$ & $0.0004^{c}$ \\
\hline $\mathrm{Se}$ & $0.73^{b}$ & $0.16^{* b}$ & $0.97^{b}$ \\
\hline $\mathrm{Rb}$ & $0.01^{c}$ & $0.38^{c}$ & 0.30 *a \\
\hline $\mathrm{Sr}$ & $0.98^{b}$ & $0.24 * c$ & $3.0 \mathrm{e}-06^{\mathrm{a}}$ \\
\hline Mo & $0.63^{c}$ & $0.31^{b}$ & $0.16 * b$ \\
\hline $\mathrm{Cd}$ & $0.03 * c$ & $0.71^{c}$ & $0.40^{c}$ \\
\hline Sn & $0.20 * b$ & $0.34^{\star a}$ & $0.75^{\star c}$ \\
\hline $\mathrm{Sb}$ & $0.70 * b$ & $0.05^{* b}$ & $0.001 * c$ \\
\hline $\mathrm{Hg}$ & $0.09^{c}$ & $0.01 * c$ & $0.0003^{c}$ \\
\hline $\mathrm{Pb}$ & $0.52^{c}$ & $0.15^{c}$ & $0.001 * c$ \\
\hline
\end{tabular}

*cannot compute exact p-values with ties (data with the same values).

Table 4. Medians and ranges of the concentration of heavy metals and trace elements in the fur (ug.g ${ }^{-1}$ ) and blood (ug.ml-1) of molossid bats sampled on the Venetia Diamond Mine and Corea Game Farm (Control site). $n=$ number of samples per tissue type and per site. 


\begin{tabular}{|c|c|c|c|c|c|c|c|c|c|c|c|c|}
\hline \multirow{3}{*}{ Element } & \multicolumn{6}{|c|}{ Fur $(n=11)$} & \multicolumn{6}{|c|}{ Blood $(n=11)$} \\
\hline & \multicolumn{3}{|c|}{ Corea Game Farm $(n=5)$} & \multicolumn{3}{|c|}{ Venetia Diamond Mine $(n=6)$} & \multicolumn{3}{|c|}{ Corea Game Farm $(n=5)$} & \multicolumn{3}{|c|}{ Venetia Diamond Mine $(n=6)$} \\
\hline & Median & Min & Max & Median & Min & Max & Median & Min & Max & Median & Min & Max \\
\hline B & 3.380 & 1.643 & 3.914 & 7.440 & 6.791 & 18.900 & 1.330 & 1.250 & 2.321 & 2.162 & 1.250 & 3.015 \\
\hline Al & 102.620 & 51.437 & 558.062 & 109.380 & 43.969 & 185.393 & 0.105 & 0.105 & 1.999 & 0.001 & 0.105 & 1.380 \\
\hline $\mathrm{K}$ & 1.330 & 0.769 & 2.137 & 3.310 & 2.536 & 7.298 & 2.390 & 1.882 & 3.416 & 2.450 & 1.882 & 3.379 \\
\hline $\mathrm{Ca}$ & 0.380 & 0.271 & 0.822 & 0.420 & 0.315 & 0.834 & 0.060 & 0.046 & 0.082 & 0.069 & 0.046 & 0.220 \\
\hline V & 0.520 & 0.339 & 1.236 & 0.280 & 0.240 & 0.402 & 0.001 & 0.001 & 0.004 & 0.001 & 0.001 & 0.013 \\
\hline $\mathrm{Cr}$ & 1.070 & 0.369 & 2.708 & 0.990 & 0.545 & 1.471 & 0.060 & 0.014 & 0.099 & 0.007 & 0.007 & 0.409 \\
\hline $\mathrm{Mn}$ & 13.330 & 6.189 & 32.612 & 4.750 & 3.232 & 8.010 & 0.150 & 0.080 & 0.347 & 0.052 & 0.080 & 0.425 \\
\hline $\mathrm{Fe}$ & 147.64 & 79.05 & 814.00 & 101.41 & 67.54 & 181.25 & 629.47 & 484.83 & 861.64 & 690.91 & 631.09 & 1026.21 \\
\hline Co & 0.240 & 0.166 & 0.673 & 0.130 & 0.096 & 0.199 & 0.001 & 0.0003 & 0.004 & 0.002 & 0.0003 & 0.004 \\
\hline $\mathrm{Ni}$ & 1.380 & 0.766 & 2.575 & 1.130 & 0.790 & 2.970 & 0.010 & 0.003 & 0.014 & 0.009 & 0.002 & 0.100 \\
\hline $\mathrm{Cu}$ & 6.090 & 5.343 & 17.413 & 8.430 & 5.686 & 26.106 & 0.380 & 0.261 & 0.665 & 0.731 & 0.261 & 0.968 \\
\hline $\mathrm{Zn}$ & 97.700 & 37.775 & 241.865 & 147.090 & 117.801 & 346.409 & 1.900 & 1.376 & 3.589 & 4.040 & 1.376 & 7.044 \\
\hline As & 0.260 & 0.184 & 0.320 & 0.720 & 0.369 & 1.201 & 0.005 & 0.003 & 0.009 & 0.006 & 0.003 & 0.023 \\
\hline $\mathrm{Se}$ & 4.030 & 1.948 & 6.396 & 5.480 & 3.645 & 8.214 & 0.600 & 0.570 & 0.731 & 0.822 & 0.570 & 1.052 \\
\hline $\mathrm{Rb}$ & 0.890 & 0.628 & 1.055 & 1.260 & 1.114 & 2.958 & 1.020 & 0.826 & 2.363 & 0.893 & 0.977 & 1.570 \\
\hline $\mathrm{Sr}$ & 1.710 & 1.369 & 3.651 & 1.440 & 1.018 & 1.854 & 0.060 & 0.027 & 0.078 & 0.079 & 0.027 & 0.383 \\
\hline Mo & 0.720 & 0.518 & 0.817 & 0.850 & 0.586 & 0.917 & 0.003 & 0.002 & 0.006 & 0.003 & 0.0006 & 0.007 \\
\hline $\mathrm{Cd}$ & 0.020 & 0.016 & 0.097 & 0.090 & 0.031 & 0.171 & 0.0003 & 0.0001 & 0.003 & 0.001 & 0.0001 & 0.004 \\
\hline Sn & 0.060 & 0.033 & 0.164 & 0.090 & 0.062 & 0.183 & 0.003 & 0.002 & 0.003 & 0.004 & 0.002 & 0.722 \\
\hline $\mathrm{Sb}$ & 0.040 & 0.019 & 0.074 & 0.180 & 0.094 & 0.223 & 0.0003 & 0.0003 & 0.0003 & 0.001 & 0.0003 & 0.003 \\
\hline $\mathrm{Hg}$ & 0.600 & 0.386 & 1.112 & 1.270 & 0.578 & 1.947 & 0.011 & 0.006 & 0.026 & 0.029 & 0.006 & 0.045 \\
\hline $\mathrm{Pb}$ & 0.480 & 0.420 & 1.465 & 0.450 & 0.156 & 0.936 & 0.011 & 0.008 & 0.038 & 0.033 & 0.008 & 0.169 \\
\hline
\end{tabular}

Figures 


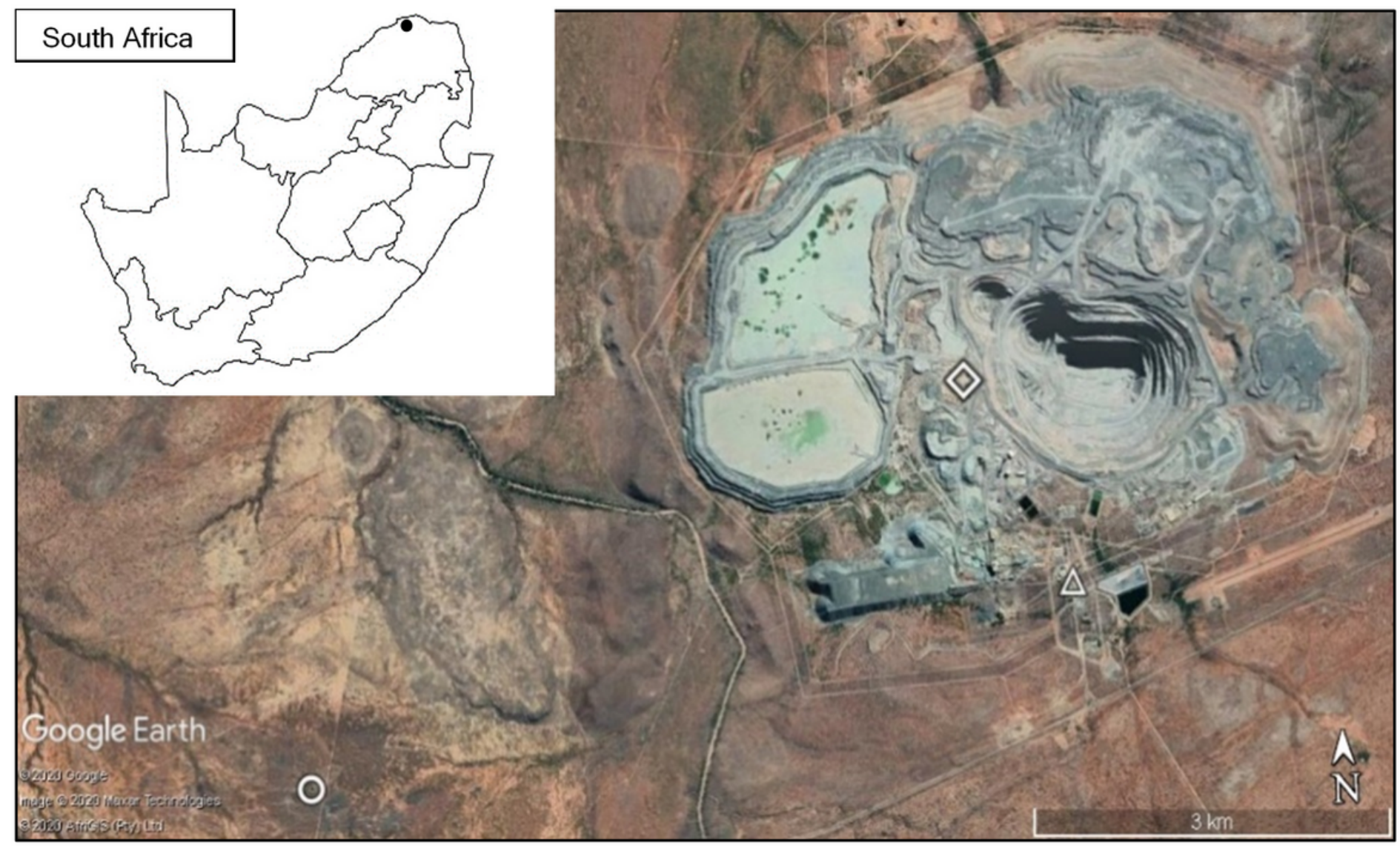

Figure 1

The layout of the study site and capture sites: the Venetia Diamond Mine (diamond shape) footprint and associate capture site (white triangle) and the control area capture site at a temporary water pan (open circle) on Corea Game Farm. The solid fill dot in the insert map of South Africa indicates the approximate location of the Venetia diamond mine in northern Limpopo Province.

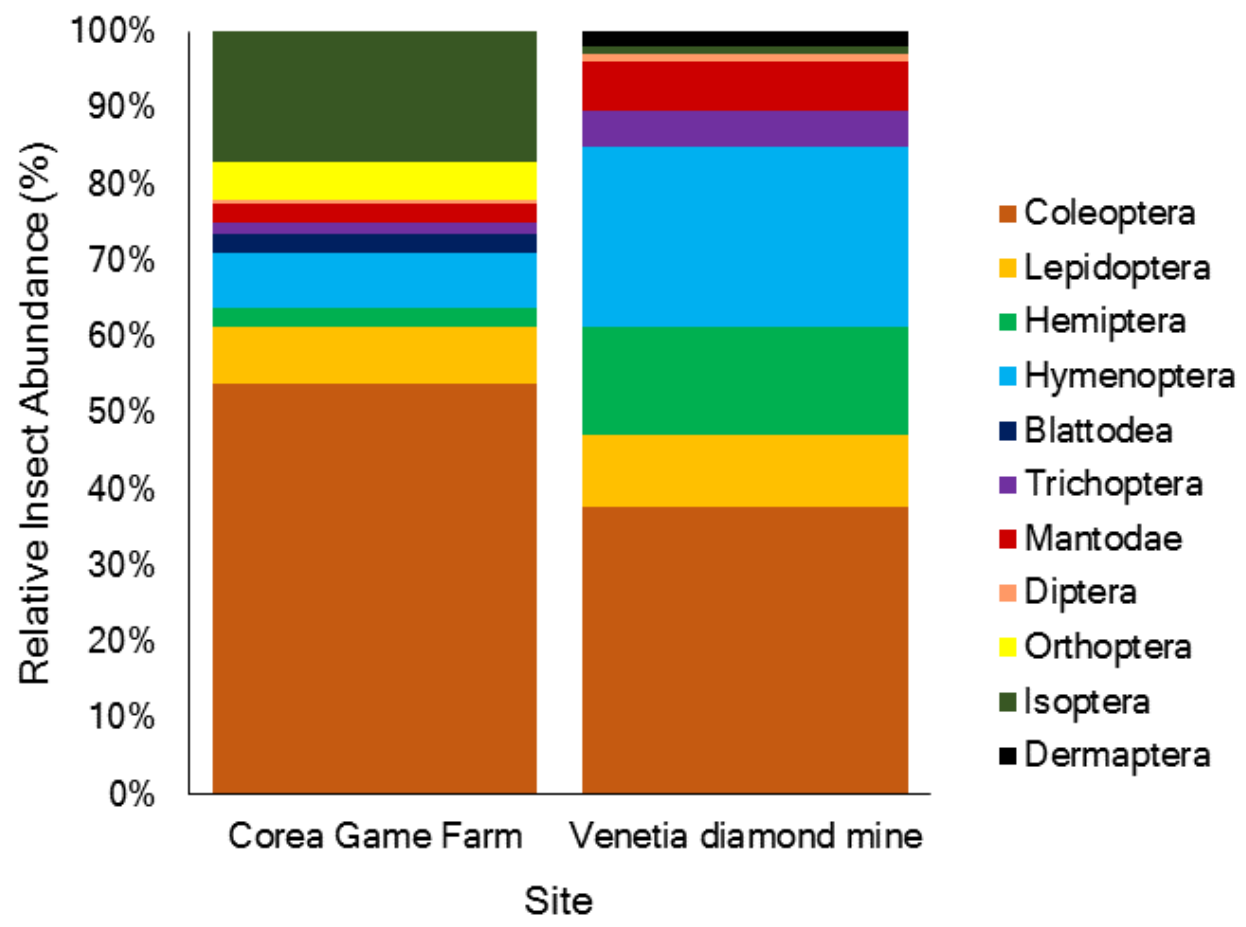

Figure 2 
Relative abundance of insect orders sampled using a light trap on Corea Game Farm ( $\mathrm{n}=2$ nights $)$ and Venetia diamond mine $(\mathrm{n}=2$ nights $)$ where Coleoptera were dominant on both sites comprising $53.92 \%$ and $37.74 \%$ of the sample respectively.

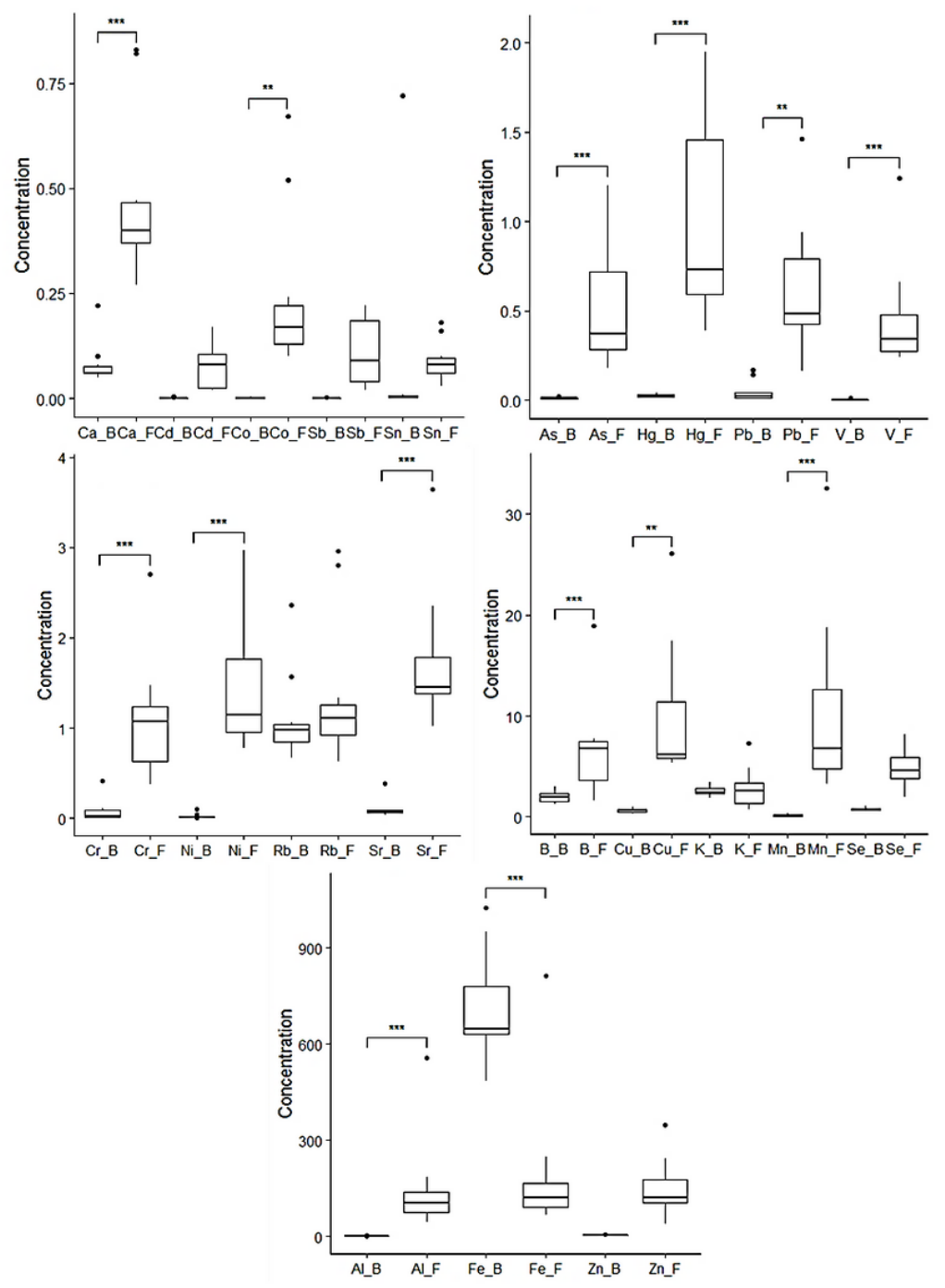

\section{Figure 3}

Box and whiskers plots indicating the median, the 25th and 75th percentiles and range of the concentrations of heavy metals and trace elements (open circles) in relation to tissue type ( $\mathrm{F}=\mathrm{fur}, \mathrm{B}=\mathrm{blood})$. Statistically significant differences between heavy metal and trace element concentrations in fur and blood are indicated as follows: ${ }^{*}=\mathrm{P}<0.05$, $* *=\mathrm{P}<0.005$, and ${ }^{*} * \mathrm{P}<0.0005$. Mann-Whitney U-tests were used to compare Al, $\mathrm{Ca}, \mathrm{V}, \mathrm{Cr}, \mathrm{Mn}, \mathrm{Ni}, \mathrm{Rb}, \mathrm{Sr}$; Anovas were used to compare $\mathrm{K}, \mathrm{Zn}$, Se, Mo; and t-tests assuming equal variances were used to compare $\mathrm{B}$, $\mathrm{Fe}, \mathrm{Co}, \mathrm{Cu}, \mathrm{As}, \mathrm{Cd}, \mathrm{Sn}, \mathrm{Sb}, \mathrm{Hg}$ and $\mathrm{Pb}$. 